\title{
Holocene wildfire regimes in forested peatlands in western Siberia: interaction between peatland moisture conditions and the composition 5 of plant functional types
}

Angelica Feurdean*1,2,3, Andrei-Cosmin Diaconu ${ }^{4}$, Mirjam Pfeiffer ${ }^{2}$, Mariusz Gałka ${ }^{5}$, Simon M. Hutchinson $^{6}$, Geanina Butiseaca ${ }^{2}$, Natalia Gorina ${ }^{7}$, Spassimir Tonkov ${ }^{8}$, Aidin Niamir, ${ }^{2}$ Ioan Tantau ${ }^{4}$, Sergey Kirpotin 7,9

10

${ }^{1}$ Department of Physical Geography, Goethe University, Altenhöferallee 1, 60438 Frankfurt am Main, Germany

${ }^{2}$ Senckenberg Biodiversity and Climate Research Centre (BiK-F), Senckenberganlage, 25, 60325, Frankfurt am Main, Germany

${ }^{3}$ STAR-UBB Institute, Babeş-Bolyai University, Kogălniceanu 1, 400084, Cluj-Napoca, Romania

15 4Department of Geology, Babeş-Bolyai University, Kogălniceanu 1, 400084, Cluj-Napoca, Romania

${ }^{5}$ Department of Biogeography, Paleoecology and Nature Conservation, Faculty of Biology and Environmental Protection, University of Lodz, Banacha 1/3, Lodz, Poland

${ }^{6}$ School of Science, Engineering and Environment, University of Salford, Salford, Greater Manchester M5 4WT, UK

${ }^{7}$ Bio-Clim-Land Center of Excellence, National Research, 634050, Tomsk State University, Tomsk, Russia

$20{ }^{8}$ Laboratory of Palynology, Faculty of Biology, Sofia University St. Kliment Ohridski, Dragan Tsankov 8, 1164 Sofia, Bulgaria

${ }^{9}$ Tuvan State University, Russia; Bio-Clim-Land" Center of Excellence, Tomsk State University, Russia

Correspondence to: Feurdean@em.uni-frankfurt.de; angelica.feurdean@gmail.com 
https://doi.org/10.5194/cp-2021-125

Preprint. Discussion started: 4 October 2021

(c) Author(s) 2021. CC BY 4.0 License.

(c) (i)

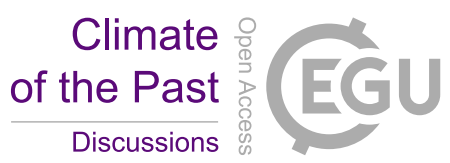

Abstract. Wildfire is the most common disturbance type in boreal forests and can trigger significant changes in forest composition. Waterlogging in peatlands determines the degree of tree cover and the depth of the burning horizon associated with wildfires. However, interactions between peatland moisture, vegetation composition and flammability, and fire regime in forested peatland in Eurasia remain largely unexplored, despite their huge extent in boreal regions. To address this knowledge gap, we reconstructed the Holocene fire regime, vegetation composition and peatland hydrology at two sites in Western Siberia near Tomsk Oblast, Russia. The palaeoecological records originate from forested peatland areas in predominantly light taiga (Pinus-Betula) with increase in dark taiga communities (Pinus sibirica, Picea obovata, Abies sibirica) towards the east. We found that the past water level fluctuated between 8 and $30 \mathrm{~cm}$ below the peat surface. Wet peatland conditions promoted broadleaf trees (Betula), whereas dry peatland conditions favoured conifers and a greater forest density (dark-to-light-taiga ratio). The frequency and severity of fire increased with a declining water table that enhanced fuel dryness and flammability and at an intermediate forest density. We found that the probability of intensification in fire severity increased when the water level declined below $20 \mathrm{~cm}$ suggesting a tipping point in peatland hydrology at which wildfire regime intensifies. On a Holocene scale, we found two scenarios of moisture-vegetation-fire interactions. In the first, severe fires were recorded between 7.5 and $4.5 \mathrm{ka}$ BP with lower water level and an increased proportion of dark taiga and fire avoiders (Pinus sibirica at Rybanya and Abies sibirica at Ulukh Chayakh) mixed into the dominantly light taiga and fire-resister community of Pinus sylvestris. The second occurred over the last $1.5 \mathrm{ka}$ and was associated with fluctuating water tables, a declining abundance of fire avoiders, and an expansion of fire invaders (Betula). These findings suggest that frequent high-severity fires can lead to compositional and structural changes in forests when trees fail to reach reproductive maturity between fire events or where extensive forest gaps limit seed dispersal. This study also shows prolonged periods of synchronous fire activity across the sites, particularly during the early to mid-Holocene, suggesting a regional imprint of centennial to millennial-scale Holocene climate variability on wildfire activity. Increasing human presence in the region of the Ulukh-Chayakh Mire near Teguldet over the last four centuries drastically enhanced ignitions compared to natural background levels. Frequent warm and dry spells predicted for the future in Siberia by climate change scenarios will enhance peatland drying and may convey a competitive advantage to conifer taxa. However, dry conditions, particularly a water table decline below the threshold of $20 \mathrm{~cm}$, will probably exacerbate the frequency and severity of wildfire, disrupt conifers' successional pathway and accelerate shifts towards more fire-adapted broadleaf tree cover. Furthermore, climate-disturbance-fire feedbacks will accelerate changes in the carbon balance of forested boreal peatlands and affect their overall future resilience to climate change.

\section{Introduction}

60 Wildfire is the most common type of disturbance in boreal forests. It can change forest composition and accelerate climate warming via carbon release into the atmosphere and alteration of the radiative balance due to changes in land surface albedo (Rogers et al., 2015; Kharuk et al., 2021). However, the impacts of wildfire on vegetation and climate strongly depend on the fire regime. High-intensity crown fires kill most trees and alter species composition for an extended period. In the short term, 
https://doi.org/10.5194/cp-2021-125

Preprint. Discussion started: 4 October 2021

(c) Author(s) 2021. CC BY 4.0 License.

\section{(c) (i)}

Climate

of the Past

Discussions

such fires release black carbon aerosols (Rogers et al., 2015). When these aerosols persist in the atmosphere, it leads to a medium-term increase in albedo and ultimately to regional cooling. Contrastingly, surface fires typically do not kill mature trees or trigger stand-scale forest replacement and have little effect on albedo. Fire regimes in the Siberian boreal forests are often litter-fuelled surface fires that infrequently transition to the crown, depending on forest composition (Sannikov and Goldammer, 1996; Grooth et al., 2013; Kharuk et al., 2021). A high diversity of fire-related plant functional types (PFT), including resisters (Pinus sylvestris, Larix sibirica, L. gmelinii), avoiders (Abies sibirica, Picea obovata, Pinus sibirica), invaders (Betula pubescens, B. pendula) and endurers (Populus tremula, B. pubescens) dominate these forests (Rowe, 1983; Agee, 1998; Wirth, 2005). Fire resisters, invaders, and endurers are commonly associated with high-frequency but lowintensity surface fire regime, whereas avoiders are associated with low-frequency but high-intensity crown fire regimes (Goldammer and Furyaev, 1996; Wirth, 2005). As these two types of fire can have a different net effect on forest composition and climate, it is essential to understand the drivers behind each fire regime to improve the prediction of the impact of changes

75 in the extent, frequency, and severity of fire in the future.

A wildfire regime emerges from the combination of ignition sources, climatic conditions, fuel properties and human activities. The interactions between these factors are spatiotemporally complex (Moritz et al., 2014). The spatial complexity of wildfire patterns is particularly accentuated in open and forested peatlands, where variability in local peat moisture content, vegetation composition and structure results in pronounced small-scale heterogeneity (Camill et al., 2009; Magnan et al., 2012;

80 Kuosmanen et al., 2014; Remy et al., 2018; Barhoumi et al., 2019; Stivrins et al., 2019; Feurdean et al., 2020a). The waterlogged conditions that prevail in peatlands can limit the burning depth of the fuel bed. However, this attenuation effect decreases with water table decline and increasing tree cover (Whitman et al., 2018). Unlike drained peatlands with shrub and tree-dominated communities, well-hydrated peatlands composed of a dense Sphagnum cover remain wet despite droughts and exhibit only slight to medium fire damage (Whitman et al., 2018; Gewin, 2020). This pattern in fire dynamics is particularly

85 concerning because climate warming accelerates woody encroachment in peatlands and increases fuel availability for forest fires (Kharuk et al., 2021). Intensification of fire severity may also lead to a shift from conifer towards broadleaf tree dominance (Kelly et al., 2013; Mekonnen et al., 2019). Understanding how hydrological conditions in peatlands are influenced by climate change and how this may interact with forest peatland composition and fuel flammability is a key research priority that remains largely unexplored (Page et al., 2009; Walker et al., 2009; Kharuk et al., 2021).

90 Reducing uncertainty in predicting future trajectories of fire regimes and the impact of changing fire activity on the functioning of boreal ecosystems requires approaches with a broad spatial and temporal scope (Kasischke et al., 2010). Forest ecosystems have long successional cycles ranging between decades and centuries. Palaeoecological records capture long time scales and are, therefore, particularly suitable to track the fire dynamics of forest ecosystems (Whitlock et al., 2018). However, studies of past millennial-scale variability in fire regimes in Siberian boreal forests started to emerge only recently (Feurdean et al.,

95 2020a; Rudaya et al., 2020; Glückner et al., 2021; Barhoumi et al., 2021). No studies have explicitly explored the interactions between peatland moisture, vegetation composition and fire regime in Siberia to this date. 
https://doi.org/10.5194/cp-2021-125

Preprint. Discussion started: 4 October 2021

(c) Author(s) 2021. CC BY 4.0 License.

(c) (i)

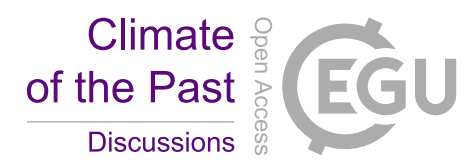

In this study, we used a multi-proxy (pollen, macrocharcoal morphologies, testate amoeba) analysis on two new peat records from Tomsk Oblast to explore the patterns and drivers of the western Siberian fire regime throughout the Holocene. Specifically, we have determined how peatland moisture has interacted with community composition (with regard in plant functional types) and fuel flammability in driving the frequency and type of fires. Combining our new data with our two other published records from the region allowed a quantification of the degree of spatiotemporal synchronicity in fire activity.

\section{Material and Methods}

\subsection{Geographical location and charcoal site selection}

The study areas stretch along a west-east transect in a permafrost-free area in Tomsk Oblast, Siberia (Bleuten and Filippov,

2008; Kirpotin et al., 2021). The region has a continental climate with subarctic influences. The mean annual temperature is $0^{\circ} \mathrm{C}$, the mean temperature of the coldest/warmest season is $-17^{\circ} \mathrm{C} / 17^{\circ} \mathrm{C}$, and the mean annual precipitation is $\sim 525 \mathrm{~mm}$ falling predominantly in the warm season (www.climexp.knmi.nl). Typical forests in this region are characterised as light taiga type composed of Pinus sylvestris, Betula pubescens, B. pendula, with a greater proportion of dark taiga, including Pinus sibirica, Picea obovata, and Abies sibirica towards the east (Berezin et al., 2014; Rybina et al., 2014). Fires, at present primarily ignited by humans (80\%), occur predominantly between spring and early autumn, but summer and autumn fires are more frequently of greater severity (Kukavskaya et al., 2014, 2016; Kharuk et al., 2021).

We cored two sites, Rybnaya Mire (N57,27566800 ${ }^{\circ}$ E84,48758900 $)$ located on the river Rybnaya, a tributary of the Ob river, and Ulukh-Chayakh Mire (N57.34326197 ${ }^{\circ}$ E88,32306189 ${ }^{\circ}$ ) located on a terrace of the Chulym river, near the village of Teguldet at the border of the Krasnoyarsk Krai (Fig. 1). The local vegetation at both coring sites includes mesotrophic open

115 sedge-Sphagnum communities with young birch trees at Rybnaya Mire and standing dead tree trunks at Ulukh-Chayakh Mire. The dead trees reflect a rise in water levels across the mire due to road construction in the $1960 \mathrm{~s}$. Peat cores $(50 \mathrm{~cm}$ length, 5 $\mathrm{cm}$ diameter) totalling $400 \mathrm{~cm}$ at Rybnaya Mire and $348 \mathrm{~cm}$ at Ulukh-Chayakh Mire were extracted with a Russian-type corer in 2017 and 2019, respectively.

\section{$120 \quad 2.2$ Chronology}

We established the chronology of both cores based on AMS radiocarbon measurements performed at Isotoptech, Debrecen, Hungary (File S1). The ${ }^{14} \mathrm{C}$ AMS age estimates were converted to calendar years BP using the IntCal20 data set of Reimer et al. (2020) and we constructed the age-depth models using the smooth spline method implemented in the CLAM software (Blaauw, 2010). In the age-depth models, we assigned a surface age of -67 (coring year 2017 for Rybnaya) and -69 (coring 125 year 2019 for Ulukh-Chayakh) to the surface samples of each sequence.

\subsection{Fire history}

\subsubsection{Charcoal-based reconstructions of fire history}


https://doi.org/10.5194/cp-2021-125

Preprint. Discussion started: 4 October 2021

(c) Author(s) 2021. CC BY 4.0 License.

\section{(c) (1)}

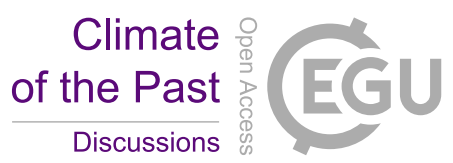

We inferred changes in local-scale fire regime based on peat samples of $2 \mathrm{~cm}^{3}$ extracted at $1 \mathrm{~cm}$ contiguous intervals (Whitlock and Larsen, 2001). Charcoal preparation, identification and the categorisation of charcoal morphotypes followed Feurdean et al. (2020a) and Feurdean (2021). To deduce the predominant fire type burnt, we pooled the charcoal morphologies into two categories: non-woody (graminoids, forbs) and woody types (deciduous leaves, wood, and resins) and calculated their ratio. These two categories represent the dominant fuel sources for surface and crown fires, respectively (Enache et al., 2006; Jensen et al., 2007; Courtney-Mustaphi and Pisaric, 2014; Feurdean et al., 2017; 2020a; Feurdean, 2021). At Ulukh-Chayakh, we additionally measured the aspect ratio (length:width) of charcoal particles in selected samples to discriminate between the relative dominance of graminoids versus leaves and wood morphologies (Feurdean, 2021; Vachula et al., 2021). We separated the charcoal fractions into two size classes $(150-500 \mu \mathrm{m}$ and $>500 \mu \mathrm{m})$ to deduce the approximative location of fires, i.e., local versus on-site fire events. We calculated the influx of charcoal morphotypes and size classes (particles $\mathrm{cm}^{-2} \mathrm{yr}^{-1}$ ) by dividing their respective concentration (particles $/ \mathrm{cm}^{3}$ ) by the sediment deposition rate determined from the age-depth models $(\mathrm{yr} / \mathrm{cm})$.

140 We estimated the frequency and severity of fire episodes using charcoal peaks identified from macrocharcoal particles using the method of Higuera et al. (2009). This methodology involved interpolating CHAR values to constant time steps (30 yr), decomposing the record into a background and a peak component (local fire episodes) using a robust LOWESS smoother (900 yr), and evaluating charcoal peaks using the 95th percentile of the modelled noise distribution. We used the signal-to-noise index (SNI) to assess the suitability of the record for peak detection (Kelly et al. 2011; File S2).

145 To integrate fire history across the study area, we created composite records of CHAR and fire frequency (FF) by combining the two new records with our two published profiles from Plotnikovo Mire (Feurdean et al., 2019; 2020a; Fig. 1). Composite CHAR was created using the Power et al. (2008) protocol implemented in the R palaeofire package version 4.0 (Blarquez et al., 2014) with the following setup for Z score transformation: $8.5 \mathrm{ka}$ to present as the base period, and LOWESS smoothing to a 25 -yr mean. The composite FF was created by pooling the identified fire events from all four records and applying a 150-

150 yr smoothing.

\subsubsection{Fire type identification from satellite images and forest statistics}

To evaluate the ability of charcoal records to capture the occurrence and severity of fires near the two sites, we used satellite imagery of vegetation cover from LANDSAT 4-5 TM, LANDSAT-7 ETM+, and LANDSAT 8 OLI/TIRS (https://earthexplorer.usgs.gov/). We also used observation-based fire data from the Forest Department of the Tomsk Region

155 from 1950 to $2020 \mathrm{CE}$ and data from MODIS sensors onboard the NASA Terra-1 and Aqua-1, which detect forest fires (http://fires.ru/). All maps and images were processed using ESRI ArcGIS version 10.8.

\subsection{Pollen-based reconstruction of vegetation dynamics}

To reconstruct past vegetation dynamics, we analysed pollen and spores mainly at $4 \mathrm{~cm}$ intervals in both profiles following the protocol of Willis and Bennett (2001). A pollen sum exceeding 500 terrestrial pollen grains, excluding Cyperaceae, was counted for most samples and converted into percentages based on the total terrestrial pollen sum. The percentages of 
https://doi.org/10.5194/cp-2021-125

Preprint. Discussion started: 4 October 2021

(c) Author(s) 2021. CC BY 4.0 License.

(c) (i)

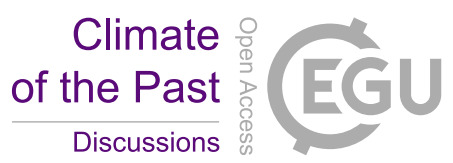

Cyperaceae, ferns and mosses were calculated relative to the terrestrial pollen sum and their respective individual sum. The bottom part of the Ulukh-Chayakh profile, i.e., from 300-340 cm (age >6500 cal yr BP), contained extremely poorly preserved pollen and was excluded from further analysis.

We assigned pollen-derived tree taxa to one of the fire-related functional PFT groups - resisters (Pinus sylvestris, Larix spp.),

165 avoiders (Picea obovata, Abies sibirica, Pinus sibirica), or invaders (Betula spp.). The PFT-specific fire coping adaptations relate to a taxon's strategy to complete its life cycle in the context of a given fire regime (Gill, 1981; Wirth, 2005). We also separated the tree composition into taxa associated with dark taiga (Pinus sibirica, Abies sibirica, Picea obovata) and light taiga (Pinus sylvestris, Betula spp., Larix spp.) and creating an index for forest density by calculating the ratio between the relative abundance of dark taiga and light taiga tree taxa (Higuera et al., 2014). Additionally, we pooled the non-arboreal pollen

170 types as shrubs, herbs, ferns and mosses. To determine the regional changes in forest composition, we created composite records of PFTs. This was done by averaging the Z-scores and smoothing them to 300 years using a locally weighted regression and a $95 \%$ confidence envelope on the same sites used for composite biomass burning reconstructions in the $\mathrm{R}$ palaeofire package.

\subsection{Climate reconstruction based on testate amoebae and water table depth}

To determine changes in peatland hydrology at each site, we used testate amoeba-based water table reconstructions. The testate amoebae preparation and identification were conducted at $4 \mathrm{~cm}$ intervals following the methods of Hendon and Charman (1997) and Charman et al. (2000). Based on the available literature (Grospietsch, 1958; Ogden and Hedley, 1980; Mazei and Tsyganov, 2006), we identified and counted a minimum of 150 testate amoebae per sample. No testate amoebae were present in core segments below $285 \mathrm{~cm}$ (age > $6000 \mathrm{ka} \mathrm{BP}$ ) in the Ulukh-Chayakh sequence. We used the transfer function developed for the pan-European region (Amesbury et al., 2016) to derive the water depth. For the composite water table reconstruction, we used the same setting as for pollen.

\subsection{Numerical methods}

185 To quantify the relationship between peatland moisture conditions, biomass burning, forest density and the relative abundances of PFTs, we performed a correlation analysis. We used microcharcoal influx (CHAR particles $>150 \mu \mathrm{m})$ as a determination of biomass burning, pollen percentages as a determination of the three PFTs (resisters, invaders, avoiders, and others) and testate amoebae-based water table depth as a determination of peatland moisture. The group "others" includes pollen and spores of shrubs, herbs, ferns and moss. Before the analysis, we interpolated all datasets fed into the model to a 100-year interval using 190 linear interpolation. We also developed generalised linear models (GLMs) to explore the response of biomass burning (CHAR) to changes in peatland moisture conditions (DTW) and to test for the existence of thresholds in the water level at which biomass burning may increase.

\section{Results}


https://doi.org/10.5194/cp-2021-125

Preprint. Discussion started: 4 October 2021

(c) Author(s) 2021. CC BY 4.0 License.

(c) (i)

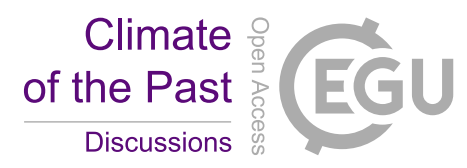

\subsection{Chronology}

The age-depth model of the Rybnaya sequence spanned $\sim$ the last 8400 years and showed a mean peat accumulation rate of 25 $\mathrm{yr} / \mathrm{cm}$ (ranging between 6-36 yr/cm). The Ulukh-Chayakh sequence may cover $\sim$ the last 8500 years, but the chronology of the bottom part of this site (>6000 years) relied on linear extrapolation and it is therefore highly uncertain (File S1). The subsequence covering the last 6000 years had an average temporal resolution of $21 \mathrm{yr} / \mathrm{cm}$ (ranging between 3-37 yr/cm).

\subsection{Site-specific and composite record of biomass burning and fire frequency}

Both records displayed a high signal-to-noise index (File S2) with almost all peaks well above 3 (a mean of 4.98 at Rybnaya and 6.45 at Ulukh-Chayakh), the theoretical minimum value for justification of peak analysis (Kelly et al., 2011). At Rybnaya, CHAR was highest between 7.5 and $6 \mathrm{ka}$ and around $4.5 \mathrm{ka}$, whereas the frequency of high-severity fires inferred from the charcoal peak magnitude and abundance of woody morphologies ranged between 1 and 2 fires/900 yr (Figs. 2a,b, 4; Files S2, S3). At Ulukh-Chayakh, CHAR was highest $>6$ and $3.5 \mathrm{ka}$, and the fire frequency varied between 2 and 5 fires/900 yr. Both profiles showed a decline towards a minimum in CHAR and frequency of severe fires i.e., low peak magnitude and reduced occurrence of woody charcoal morphologies, approximately between 4 and 1.5 ka (3-1.5 ka at Ulukh-Chayakh). The CHAR increased towards the present at both sites, but the charcoal peak amplitude was considerably higher at Ulukh-Chayakh.

210 The composite CHAR record showed augmented regional biomass burning between 7.5 and 4 ka (positive Z-scores) with peaks centred at 7.5 and $4.5 \mathrm{ka}$ (Fig. 5). We found a pattern of CHAR decline towards a minimum in the composite profiles between 4 and $2 \mathrm{ka}$ (negative Z-scores), followed by another increase between $2 \mathrm{ka} \mathrm{BP}$ to the present (positive Z-scores). The composite fire frequency showed an increase until ca. 5-4.5 ka and then again from $2 \mathrm{ka}$ to the present.

\subsection{Site-specific and composite record of vegetation composition and forest density}

Early Holocene data is only available from the Rybanya site ( 8.5 and $7.5 \mathrm{ka} \mathrm{BP})$, indicating that light taiga and the fire-invader Betula were most abundant (up to 60\%) during that period, whereas other light taiga fire-resisters (Pinus sylvestris) and dark taiga and fire avoiders (mainly Picea obovata), had an abundance of 10\% and 5\%, respectively (Fig. 3; File S4a). The high proportion of light taiga resulted in a low forest density (dark-to-light taiga ratio of 0.1). Denser forests, with an increased dark-to-light taiga ratio (> 0.2), were identified between 7.5 and $4 \mathrm{ka}$ at Rybnaya and between 5 and $2.5 \mathrm{ka}$ at Ulukh-Chayakh (Fig. 5; File S4a,b). The light taiga was composed of up to 70\% fire-resisters (Pinus sylvestris and Larix spp.), while the dark taiga, with its fire avoiders (Pinus sibirica, Picea obovata, and Abies sibirica), made up to $25 \%$ of the forest. A decline in fireresisters (down to 50\%) and forest density and increasing invader abundance (up to 60\%) occurred after 4.5 ka at Rybaya and after $2.5 \mathrm{ka}$ at Ulukh-Chayakh, indicating a change in forest composition. Between-site variability was highest within the avoider group. Picea obovata had higher values at Rybnaya (up to 10\%) than at Ulukh-Chayakh (3\%), whereas Abies sibirica was more abundant at Ulukh-Chayakh (15\%) than at Rybnaya (7\%; Fig. 4). The composite vegetation record showed a higher proportion of fire-resisters between 7.5 and $5 \mathrm{ka}$, fire avoiders between 7.5 and $3 \mathrm{ka}$, and fire invaders over the last $4.5 \mathrm{ka}$ (Fig. $5)$. 
https://doi.org/10.5194/cp-2021-125

Preprint. Discussion started: 4 October 2021

(c) Author(s) 2021. CC BY 4.0 License.

(c) (i)

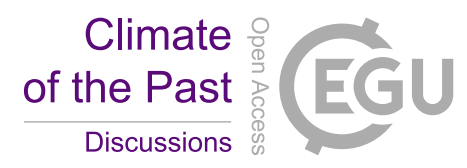

Understory vegetation primarily reflects local peatland development. It was predominantly composed of herbs/sedges

(Cyperaceae) and ferns (Polypodiaceae and Equisetum) at both sites, with more shrubs (Ericaceae) at Rybnaya and Ericaceae and moss (Sphagnum) at Ulukh-Chayakh over the last 4.5 ka (Fig. 3; File S4a,b). The sum and individual levels of herbaceous taxa, including those potentially related to human impact (Artemisia, Asteraceae, Chenopodiaceae, Urticaceae, Brassicaceae, Plantago lanceolata), were constant throughout the profiles. However, their abundance increased slightly over the last $1.5 \mathrm{ka}$ (Fig. 3; File S4a,b).

\subsection{Site-specific and composite records of peatland moisture conditions}

At Rybnaya, the testate amoeba-based reconstruction of the water table indicated relatively high levels (around $15 \mathrm{~cm}$ below surface) between 8.5 and $7.5 \mathrm{ka}, 4$ and $2.5 \mathrm{ka}$, and over the last $1 \mathrm{ka}$ (Fig. 4). We reconstructed low levels (20-30 cm below surface) for the time interval between 7.5 and $4.5 \mathrm{ka}$ and 2.5 and $1 \mathrm{ka}$ (Fig. 5). At Ulukh-Chayakh, the water table was high 240 between 3.5 and $2.5 \mathrm{ka}, 2$ and $0.5 \mathrm{ka}$, and towards the present day. There, times of low water table occurred between 6 and 3.5 $\mathrm{ka}, 2.5$ and $2 \mathrm{ka}$, and around $0.5 \mathrm{ka}$. The composite record of the water table showed high levels approximately between 8.5 to $7.5 \mathrm{ka}, 3.5$ and $3 \mathrm{ka}$ and during the last $1.5 \mathrm{ka}$, and low levels between 7.5 and $4.5 \mathrm{ka}$, and around $2.5 \mathrm{ka}$ (Fig. 5).

\subsection{Numerical analysis}

245 The correlation analysis at both sites showed that the decline in water table position (higher values representing drier conditions) was positively associated with the proportion of fire avoiders, resisters, and forest density, and negatively with invaders and others (Fig. 6a, b). Although the correlation coefficients were stronger for Rybnaya than Ulukh-Chayakh, none of these were statistically significant (Appendix A1). The generalised linear model showed no significant influence of water levels above $20 \mathrm{~cm}$ on the probability of fire occurrence and severity at both sites (Fig. 6c,d). However, a drop in water level

250 below $20 \mathrm{~cm}$ contributed statistically significantly to the increase in fire occurrence and severity at Rybnya but had no statistically significant influence at Ulukh-Chayakh.

\section{Discussion}

\subsection{Changes in fuel, fire type and fire frequency over the Holocene}

255 Stand-replacing fires combust substantial amounts of biomass because they burn entire trees. Such fires manifest themselves in a greater abundance of charcoal particles that exceed the quantities typically produced by surface fires. This feature allows a distinct separation of charcoal peaks from charcoal background levels, which yields a higher signal-to-noise index (Higuera et al., 2005; 2009; Courtney Mustaphi and Pisaric 2014). Indeed, the comparison of sedimentary charcoal from sub-recent samples with satellite imagery of the region (Plotnikovo Mire) has confirmed that the marked increase in charcoal particles 260 towards the present day at this location, closely agrees with the occurrence of high-severity fires (Feurdean et al., 2020a). Satellite images and official forest statistics show no evidence of recent fires in the vicinity of the current study sites, except for a small fire documented in 1993 near the Ulukh-Chayakh site (Fig.1). This aligns with the scarcity of charcoal peaks (1-2 
https://doi.org/10.5194/cp-2021-125

Preprint. Discussion started: 4 October 2021

(c) Author(s) 2021. CC BY 4.0 License.

\section{(c) (i)}

pieces) from sub-surface samples in both cores (Fig. 2). A high-severity fire event occurred in 2015 some ca. $30 \mathrm{~km}$ from Ulukh-Chayakh, which is not documented in our surface charcoal record and corroborates the localised origin of charcoal found in this sedimentary profile. Samples from the Ulukh-Chayakh site show a minor increase in charcoal (2-7 pieces) ca. fifty years ago, possibly related to a local fire event in 1993. The first clear charcoal peak at this site (250 pieces), with numerous wood fragments, was found ca. 200 years ago, whereas the preceding charcoal peak (400 pieces) was ca. 900 years ago (Fig. 2a,b; File S3). These two peaks therefore demonstrate the intermittent occurrence of infrequent, high-severity local fires that produce large quantities of charcoal, embedded in what is otherwise predominately a surface fire type regime generating low levels of charcoal. It also indicates that the charcoal peak extraction method applied here reliably reflects the occurrence of high-severity local fires.

We reason that the prevalence of a high charcoal influx with well-defined charcoal peaks and abundant woody morphotypes found between ca. 7.5 and 4 (3) ka at both sites, and over the past $1.5 \mathrm{ka}$ at Ulukh-Chayakh, is indicative of the predominance of high-severity local fires (Fig. 2; File S3). Between 4 (3) and $1.5 \mathrm{ka}$, the observed low charcoal influx and peak magnitude were coupled with a lower abundance of woody morphologies at both sites, although the latter feature was more pronounced at Ulukh-Chayakh (Fig. 2; File S3). For this period, we inferred predominately low-temperature surface fires that mostly burned understory biomass. Experimental production of charcoal additionally provides evidence that graminoids and Sphagnum produce little charcoal during high-temperature fires (Hudspith et al., 2017; Feurdean, 2021). Measurements of aspect ratio and surface area on selected charcoal samples at Ulukh-Chayakh show that the aspect ratio only partially agrees with the predominant fuel type inferred from charcoal morphologies. A lower aspect ratio of charcoal particles, typical for wood and leaf morphotypes, was what we expected at times of increased woody morphologies, and an increased aspect ratio with a rise in the relative proportion of graminoids (Feurdean, 2021; Vachula et al., 2021). This is probably the results of a mixed morphology of charcoal types in the same sample (Fig. 2). The overlapping morphologies of leaves and wood from trees and shrubs in the same sample also make it hard to distinguish between the dominant fire type as high-severity surface

285 fires can combust both living shrubs and dead wood and leaves. Our measurements of the surface area indicate high values at times of an increased abundance of leaves (Fig. 2; File S3) with a typically high surface area (Crawford and Belcher, 2014; Feurdean, 2021), but also with the presence of larger size particles, which complicates any interpretation of a link between charcoal surface area and the increased predominance of leaves.

Our reconstructed fire return interval is $\sim 450 \mathrm{yr}$ ( 2 fires/900 yr) throughout most of the Holocene (Fig. 4). However, fire 290 frequency (at Rybnaya) and severity (at Ulukh-Chayakh) increased over the last 1.5-2 ka BP compared to the long-term averages of both records suggesting an intensification of fire activity during the most recent two millennia. The composite fire frequency derived from all four records also shows increasing biomass burning and fire frequency over the last 2-1.5 ka (Fig. 5). The reconstructed fire return interval (FRI) in the study area is in line with those from other sites located in forested peatlands (Pinus-Betula dominated, Picea obovata, Abies sibirica) in Russia, which report an FRI range between 100 and 600 295 yr (Barhoumi et al., 2019, 2020). In contrast to these studies, we have not found a gradual increase in fire frequency from the early Holocene towards the present, but rather two distinct periods of enhanced activity, between 7.5 and 4 ka, and 
https://doi.org/10.5194/cp-2021-125

Preprint. Discussion started: 4 October 2021

(c) Author(s) 2021. CC BY 4.0 License.

\section{(c) (1)}

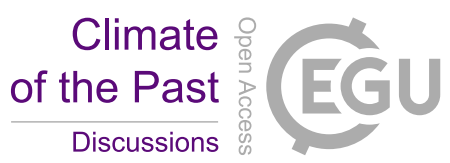

approximately over the last $2 \mathrm{ka}$ (Fig. 5). A similar increase in fire frequency during the last two millennia has also been recorded at other sites in southern Siberia, such as Lake Baikal (Bourhami et al., 2021) and in the Altai Mountains (Rudaya et al., 2020).

\subsection{Drivers of vegetation and fire regime change}

Climate conditions influence peatland moisture, fuel dryness, flammability and the composition of moisture- and fire-related PFTs. The relative abundances of the fire-related PFTs, in turn, influences the prevalence of specific fire regime types, e.g., low-intensity vs. high-intensity. Below, we discuss how climate change affects hydrological conditions in peatlands. We also highlight how climate and hydrology interact with forest and peatland plant composition, and fuel flammability.

\subsubsection{The influence of climate on peatland moisture and fuel flammability}

Waterlogging in peatlands can limit fire severity and the burning depth in the peat. Moreover, the waterlogged horizon provides a deeper substrate that can serve as a seedbed for post-fire regeneration (Whitman et al., 2018; Gewin 2020). However, increasingly dry peatland conditions and consequently of the tree cover can reduce the limiting effect of waterlogging on fire severity (Magnan et al., 2012; Kettridge et al., 2015; Whitman et al., 2018; 2019). Deep burns can even smoulder over winter and re-ignite the following spring (Scholten et al., 2021). Our water table reconstructions indicate that the water level fluctuated between 8 and $30 \mathrm{~cm}$ below the peat surface and was around $20 \mathrm{~cm}$ at both sites during large parts of the Holocene (Fig. 4). We found that the probability of occurrence and intensification of fire severity was greater at times when the water level dropped below $20 \mathrm{~cm}$ (drier conditions), and lower at water levels between 10 and $20 \mathrm{~cm}$ below the surface (wetter conditions), a pattern that is more evident at Rybnaya (Fig. 6 c,d). The stronger moisture-fire relationship at Rybnaya may be related to the higher amplitude of changes in local hydrological states and the overall drier conditions at this site $(8-30 \mathrm{~cm})$ compared to Ulukh-Chayakh (10-23 cm), which remained moister over the Holocene (Fig. 6). Water tables of mesotrophic mires are coregulated by the difference between precipitation $(\mathrm{P})$ and evapotranspiration $\left(\mathrm{E}_{\mathrm{t}}\right)$ and external water inflow. The detrital element $\mathrm{Ti}$, a possible indicator of water influx, was high in the bottom profiles that were rich in minerogenic material. Ti increased between 4 and $3 \mathrm{ka}$ and 1.5-0.1 ka at Ulukh-Chayakh and only slightly over the last $1 \mathrm{ka}$ at Rybnaya (File S5). This evidence suggests that, except of these time intervals, the water table reconstructions primarily reflect the P-E $\mathrm{E}_{\mathrm{t}}$ balance.

At a Holocene scale, the intensity of fires and/or fire size was greatest between 7.5 and $6.5 \mathrm{ka}$ and 5 and $4 \mathrm{ka}$, but not fully synchronous between the sites (Figs. 4, 5). From 9 to $4.5 \mathrm{ka}$, annual temperatures in the Northern Hemisphere were up to $3.5^{\circ} \mathrm{C}$ warmer than at present (Fig. 5) and exhibited a more pronounced seasonality, i.e., higher summer and lower winter temperatures (Kauffman et al., 2020; Bova et al., 2021). Proxy records from Siberia attest to warmer and drier-than-present climate conditions between 9 to $6 \mathrm{ka}$ and a temperature and moisture optimum between 6 and $4.5 \mathrm{ka}$ BP (Groisman et al., 2012). Warm summer temperatures likely enhanced evapotranspiration and consequently lowered peatland water levels, leading to drier surface conditions (Fig. 5). These conditions, in turn, increased fuel flammability, allowed a denser tree cover to establish on the peatlands and fostered enhanced fire severity (see 4.3). 
https://doi.org/10.5194/cp-2021-125

Preprint. Discussion started: 4 October 2021

(c) Author(s) 2021. CC BY 4.0 License.

(c) (i)

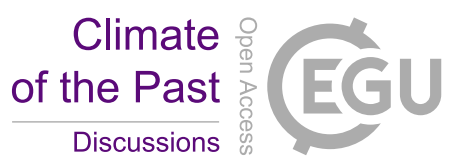

Contrastingly, the interval of lowest biomass burning and fire severity approximately between 4 (3) and 1.5 ka BP coincides with one of the periods of wettest peatland conditions during the Holocene (at Rybnaya) or a highly fluctuating water table (at Ulukh-Chayakh; Fig. 4) Annual and summer temperatures declined after 4.5 ka to values below the present day (Kauffman et al., 2020; Bova et al., 2021). Regionally, this cooling trend, which started at approx. $4.5 \mathrm{ka}$ (Groisman et al., 2012) led to high fuel moisture and reduced fuel flammability. Although biomass burning and the frequency of severe fires show more centennial-scale variability over the past $1.5 \mathrm{ka}$, this only partially matches known climatic fluctuations, such as the Medieval Climate Anomaly (MCA1200-650 cal yr BP) and the Little Ice Age (LIA; 700-400 cal yr BP). Notably, an increased charcoal peak amplitude occurred during the second part of the LIA (400-200 cal yr BP), at times of extremely wet conditions (Fig.4). We hypothesise that the climatic linkage between the cool and wet conditions that imply high fuel moisture conditions and typically low fire activity was likely disrupted by anthropogenic activity (Fig 3; File S4a, b). Historical records indicate the widespread colonisation of the region by the Russians at this time that was associated with the conversion of forest to arable land and pastures, and likely increased anthropogenic ignitions (Naumov, 2006). Most recently, local fire suppression near the village of Teguldet may have hampered contemporary fire spread on the mire leading to the recent pattern of low fire activity.

\section{4.3 Feedbacks between peatland moisture, community PFT composition and fire regime}

Peatland moisture conditions affect the relative abundances of PFTs. Fire-related PFTs, in turn, create positive or negative feedbacks for fire regimes via specific fire-related traits (Feurdean et al., 2020a; Kharuk et al., 2021). We found a dominance of open light taiga species and fire invaders (Betula spp) at times of higher water table (wet conditions) between 8.5 and 7.5 ka and after 4.5 and $3.5 \mathrm{ka}$ (Figs. 2, 4). However, Betula spp. also remained dominant during the periods of water table decline recorded between 2.5 and $1.5 \mathrm{ka}$. B. pubescens grows on wet peatlands, whereas B. pendula grows more frequently on drier soils and peatlands with higher fire incidence (Wirth, 2005; Groisman et al., 2012). Unfortunately, pollen analysis cannot differentiate the prevalence of birch species with contrasting hydrological and fire tolerances because their pollen is too similar. Denser forests of light taiga and fire-resisters (Pinus sylvestris) prevailed between 7.5 and $4.5 \mathrm{ka}$. Dark taiga taxa and fire avoiders, primally Pinus sibirica at Rybanya and Abies sibirica at Ulukh Chayakh (only from $5.5 \mathrm{ka}$ ), intersperse these forests

355 (Fig.3; File S4a,b). This forest composition coincides with drier peatland conditions and an increased severity in fires. Although not statistically significant, our correlations suggest a positive association between a high-water level and Betula, and low water level conditions with all conifer types (Fig. 6 a,b). We deduce from this a greater tolerance of broadleaf trees to wetter conditions compared to conifers. Visual trends and correlation reveal that the biomass burning increase with forest density was probably connected to dry peat conditions (Figs. 4, 6). The greatest biomass burning was found for intermediate forest density indices from 0.15 to 0.3 (max. 0.6; Fig. 4). This finding is consistent with emerging evidence on fire-fuel relationships in boreal forests, which points to a higher fire hazard in less dense than denser forests, which allow fuel to dry (Scheffer et al., 2012; Feurdean et al., 2020b).

The presence of the fire-resister, such as Pinus sylvestris, in Siberia is associated with a light surface fire regime (mean FRI of 28 years) that alternates with longer-term (mean FRI of $200 \mathrm{yr}$ ) stand-replacing crown fires (Ivanova, 2005; Kukavskaya et 
https://doi.org/10.5194/cp-2021-125

Preprint. Discussion started: 4 October 2021

(c) Author(s) 2021. CC BY 4.0 License.

(c) (i)

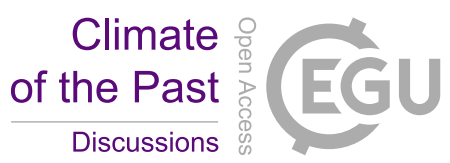

365 al., 2016). Fire avoiders typically experience severe stand-replacing crown fires at relatively long return intervals (mean FRI 150 years; range 99 and 300 years; Goldammer and Furyaev, 1996; Schulze et al., 2005; Wirth, 2005; Kharuk et al., 2021). The post-fire regeneration pathway of conifer species involves recruitment directly after burning ( $P$. sylvestris) or after an early successional phase initiated by Betula (Pinus sibirica, Picea obovata, and Abies sibirica). A mixed taiga forest with broadleaf trees and dark taiga conifer taxa typically develops between 60-120 years after a fire, followed by the dominance of conifers as a late-successional stage (Tautenhahn et al., 2016; Coop et al., 2020; Kharuk et al., 2021). We reason that the prevailing periodicity of severe fires (every 180 to 450 years) between 7.5 and 4.5 ka provided a fire-free period that was long enough for the fire avoiders Pinus sibirica, Picea obovata, and Abies sibirica to reach reproductive age. Alternatively, burning may have been too patchy to create sufficiently large forest gaps to limit seed dispersal and inhibit post fire recovery. Pinus sibirica is typically classified as a fire avoider but behaves like a fire resister when reaching old age, which could also explain

375 its increased presence at times of high fire activity. Fire also allows dark taiga species to compete with $P$. sylvestris and become established beyond poor soils and boggy areas (Kharuk et al., 2021).

A different fire regime and altered vegetation feedbacks emerged over the last two millennia at Ulukh-Chayakh, the site that experienced more severe fire episodes. It should be acknowledged that each identified fire peak could have come a few consecutive fire events that we were not able separate using the charcoal records. The intensification of local fire severity at

380 Ulukh-Chayakh paralleled a decline in the proportion of fire avoiders (mostly Abies sibirica and Picea obovata), an increase in fire invaders (Betula) and the abundant occurrence of heathland shrubs (Figs. 3. 4). Shrubs burn hotter than other surface fuel types and reach temperatures that kill most conifer seedlings (Tautenhahn et al., 2016). High severity burned areas have also been found to be more prone to repeated burning and have a more negative impact on conifers (Kukavskaya et al., 2016; Whitmann et al., 2019; Coop et al., 2020). We propose that the intensification in fire severity at Ulukh-Chayakh may have 385 eliminated mature Abies sibirica and Picea obovata, limited their seed dispersal and disrupted their successional pathways. These dynamics further resulted in a shift in forest composition towards more post-fire-adapted invader communities with better dispersal capabilities, recruitment strategies for burned areas, and rapidly maturing taxa. Our results support emerging findings of increases in broadleaf trees (Betula or Populus) at the expense of evergreen conifers that are associated with contemporary warming and increasing fire severity in forests in Siberia and North America (Kelly et al., 2013; Tautenhahn et

390 al., 2016; Mekkonen et al., 2019; Whitman et al., 2019; Kharuk et al., 2021). At Rybnaya, the modest increase in biomass burning over the past two millennia coincided with wet conditions and a forest composition remaining dominated by Betula, indicating that fire has played a more limited role in forest dynamics at this site.

\section{Conclusion}

395 This study provides novel insights into past fire regime based on Holocene records from forested peatlands in western Siberia. It demonstrates that peatland hydrology is a critical determinant of fuel dryness, plant community composition (in terms of fire-related plant functional types) and fire regime. Wet peatland conditions promoted open forests with broadleaf trees typically classified as light-taiga taxa and fire invaders (Betula), whereas dry peatland conditions facilitated conifers and 
https://doi.org/10.5194/cp-2021-125

Preprint. Discussion started: 4 October 2021

(c) Author(s) 2021. CC BY 4.0 License.

(c) (1)

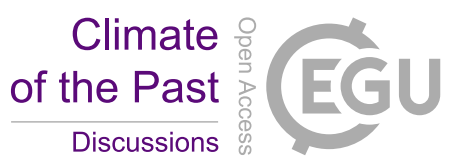

greater forest density. Although the probability of fire occurrence on these peatlands increased with drier conditions and forest

400 density, the greatest fire incidence occurred when the water level declined below $20 \mathrm{~cm}$ and at an intermediate forest density. At a Holocene timescale, we found two scenarios of moisture-vegetation-fire interactions. In the first, an enhanced fire severity episode occurred between 7.5 and $4.5 \mathrm{ka}$ and was associated with a low water level and a higher proportion of dark taiga/fire avoider taxa (mainly Pinus sibirica at Rybnaya and Abies sibirica at Ulukh Chayakh) in a light taiga and fire resister (Pinus sylvestris) dominant community. However, the second period of increased fire severity (i.e., ca. last $1.5 \mathrm{ka}$ ) coincided with a 405 reduced abundance of fire avoiders (mostly Abies sibirica and Picea obovata) and an expansion of fire invaders (Betula). These community changes demonstrate that frequent fires of higher severity can lead to compositional changes in forests, either because the trees could not reach their reproductive age between burning events or the fires created substantial forest gaps that hindered seed dispersal. This study also shows certain prolonged periods of synchronous fire activity across sites, suggesting that the magnitude of centennial to millennial-scale climate variability over the Holocene was marked enough to

410 drive fire regimes on a regional scale.

Based on our findings from fossil records, the frequent warm and dry spells predicted in Siberia for the future by climate change scenarios will likely enhance peatland drying and may convey a competitive advantage to some conifers, especially Pinus sylvestris. But dry peatland conditions, particularly water levels below $20 \mathrm{~cm}$, will also exacerbate the likelihood of fire frequency, increase their severity, and likely disrupt the successional pathway of other typical taiga conifers, notably that of 415 fire avoiders. Such a fire regime change may accelerate a shift towards broadleaf fire invader-type trees. Future climatedisturbance-fire feedbacks will not only accelerate changes in boreal forest structure and composition, but also impact the carbon balance of the forested peatlands and ultimately lead to albedo-mediated feedbacks on the regional climate system.

\section{Appendices}

\section{Appendix A1.}

Correlation coefficients for Rybnaya (a) and Ulukh-Chayakh (b). 
https://doi.org/10.5194/cp-2021-125

Preprint. Discussion started: 4 October 2021

(c) Author(s) 2021. CC BY 4.0 License.

(c) (i)
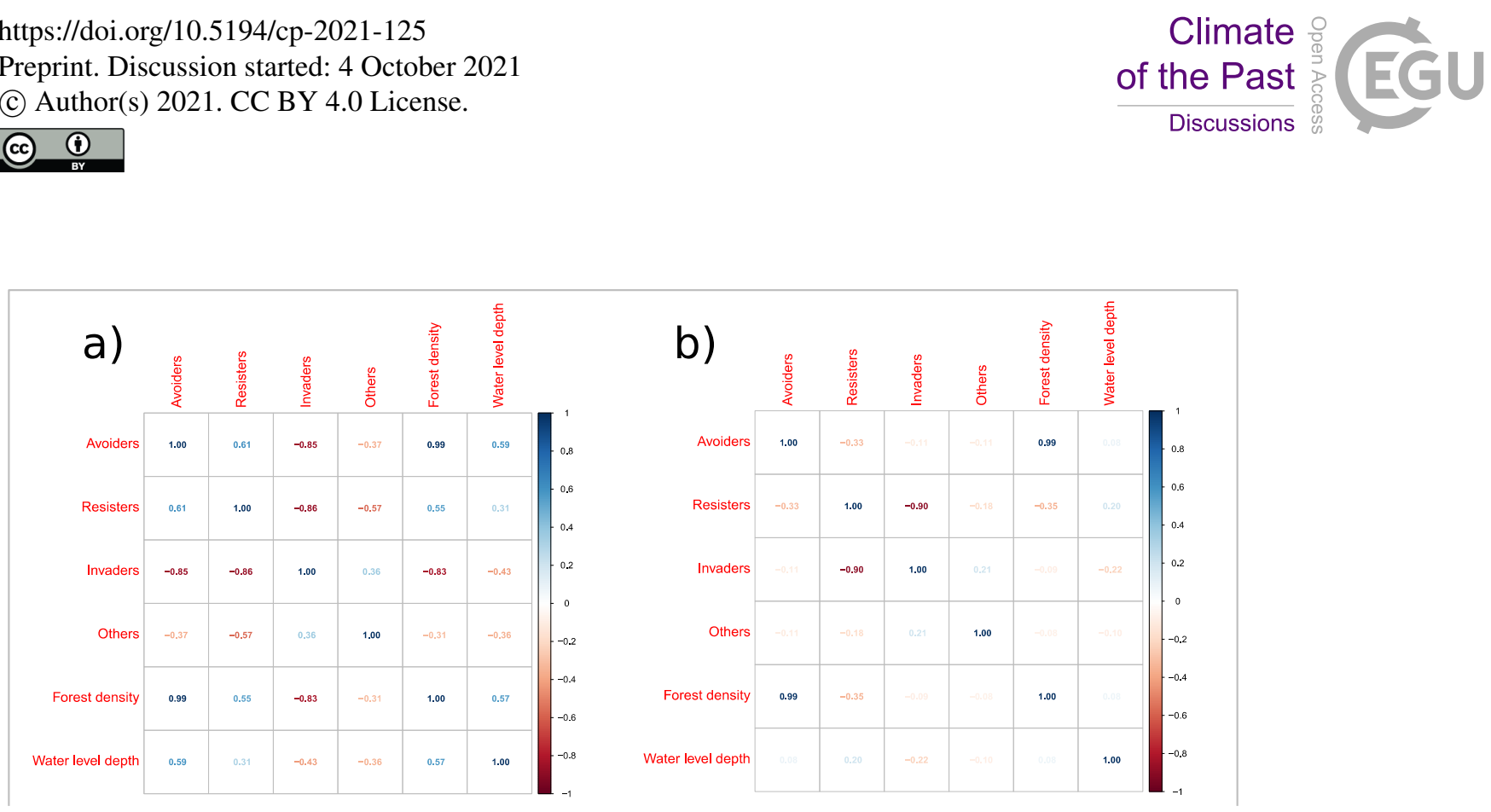

Data availability

430 All data generated for this paper will be deposited in Neotoma database upon publications.

\section{Author contribution}

Conceptualization: AF; Methodology: AF, ACD, MG, SMH, GB, NG, ST, IT, SK; Investigation and writing: AF prepared the manuscript with contribution from MF and SMH; Editing: ACD, MG, GB, NG, ST, AN, IO, SK; Funding acquisition: AF.

Competing interests: The authors declare that they have no conflict of interest.

\section{Acknowledgements}

We thank Rosa Rytkönen, University of Manchester for her help during fieldwork.

\section{Funding}

This research was supported by the German Research Foundation (grant no. FE-1096/6-1). SK is grateful for support from the Russian Science Foundation (No. 20-67-46018). 
https://doi.org/10.5194/cp-2021-125

Preprint. Discussion started: 4 October 2021

(c) Author(s) 2021. CC BY 4.0 License.

\section{(c) (1)}

Climate
of the Past

Discussions

\section{References}

Amesbury, M.J., Swindles, G.T., Bobrov, A., Charman, D.J., Holden, J., Lamentowicz, M., Mallon, G., Mazei, Y., Mitchell, E.A.D., Payne, R.J., Roland, T.P., Turner, T.E., and Warner, B.G.: Development of a new pan-European testate amoeba transfer function for reconstructing peatland palaeohydrology. Quat. Sci. Rev. 152, 132-151, https://doi.org/10.1016/j.quascirev.2016.09.024, 2018.

450 Andela, N., Morton, D. C., Giglio, L., Chen, Y., van der Werf, G. R., Kasibhatla, P. S., DeFries, R. S., Collatz, G. J., Hantson, S., Kloster, S., Bachelet, D., Forrest, M., Lasslop, G., Li, F., Mangeon, S., Melton, J. R., Yue, C., and Randerson, J.T.: A human-driven decline in 10 global burned area, Science, 356, 1356-1362, https://doi.org/10.1126/science.aal4108, http://science.sciencemag.org/content/356/6345/ 1356, 2017.

Bennett, K.D., Willis, K.J., 2001. Pollen. In: Smol, J.S., Birks, H.J.B., Last, W.M. (Eds.): Tracking Environmental Change Using Lake Sediments. Kluwer Academic Publishers, Dordrecht, pp. 5-32.

Blaauw, M.: Methods and code for 'classical' age-modelling of radiocarbon sequences. Quaternary Geochronology 5, 512518, https://doi.org/10.1016/j.quageo.2010.01.002, 2010.

Blarquez, O., Vannière, B., Marlon, J.R., Daniau, A.-L., Power, M.J., Brewer, S., and Bartlein, P.J.: Paleofire An R package to analyse sedimentary charcoal records from the Global Charcoal Database to reconstruct past biomass burning. Computers \& Geosciences, 72, 255-261, https://doi.org/10.1016/j.cageo.2014.07.020, 2014.

Barhoumi, C., Peyron, O., Joannin, S., Subetto, D., Kryshen, A., Drobyshev, I., Girardin, M.P., Brossier, B., Paradis, L., Pastor, T., and Alleaume, S.: Gradually increasing forest fire activity during the Holocene in the northern Ural region (Komi Republic, Russia). The Holocene, 29906-20, https://doi.org/10.1177/0959683619865593, 2019.

Barhoumi, C., Ali, A.A., Peyron, O., Dugerdil, L., Borisova, O., Golubeva, Y., Subetto, D., Kryshen, A., Drobyshev, I.,

Ryzhkova, N., and Joannin, S.: Did long-term fire control the coniferous boreal forest composition of the northern Ural region (Komi Republic, Russia) J. Biogeogr., 47, 2426-2441. https://doi.org/10.1111/jbi.13922, 2020.

Barhoumi, C., Vogel, M., Dugerdil, L., Limani, H., Joannin, S., Peyron, O., Ali, A.A.: Holocene Fire Regime Changes in the Southern Lake Baikal Region Influenced by Climate-Vegetation-Anthropogenic Activity Interactions. Forests, 12, 978, https://doi.org/10.3390/f12080978, 2021.

Bleuten, W., and Filippov, I.: Hydrology of mire ecosystems in central West Siberia: the Mukhrino field station. in: Glagolev, M.V., Lapshina, E.D. (Eds.), Transactions of UNESCO Department of Yugorsky State University Dynamics of Environment and Global Climate Change, https://doi.org/10.17816/edgcc11S208-224, 2008.

Berezin, A.E., Bazanov, V.A, Skugarev, A.A. Rybina, T.A., and Parshina N.V.: Great Vasyugan Mire: landscape structure and peat deposit structure features. International Journal of Environmental Studies, 71, 618-623, https://doi.org/10.1080/00207233.2014.942537, 2014.

Bova, S., Rosenthal, Y., Liu, Z., Godat, S.P., Yan, M.: Seasonal origin of the thermal maxima at the Holocene and the last interglacial. Nature 589, 548-553, https://doi.org/10.1038/s41586-020-03155-x, 2021. 
https://doi.org/10.5194/cp-2021-125

Preprint. Discussion started: 4 October 2021

(c) Author(s) 2021. CC BY 4.0 License.

\section{(c) (1)}

Camill, P., Barry, A., Williams, E., Andreassi, C., Limmer, J., and Solick, D.: Climate vegetation-fire interactions and their impact on long-term carbon dynamics in a boreal peatland landscape in northern Manitoba, Canada. Journal of Geophysical Research, 114, G04017, https://doi.org/10.1029/2009JG001071, 2009.

Charman, D.J., Hendon, D., and Woodland, W.A.: The Identification of Testate Amoebae (Protozoa: Rhizopoda) in Peats. Technical Guide No. 9. Quaternary Research Association, London, 2000.

Coop, J.D., Parks, S.A., Stevens-Rumann, C.S., Crausbay, S.D., Higuera, P.E., Hurteau, M.D., Tepley, A., Whitman, E., Assal, T., Collins, B.M., and Davis, K.T.: Wildfire-driven forest conversion in western North American landscapes. BioScience, 70, 659-73, https://doi.org/10.1093/biosci/biaa061, 2020.

Courtney-Mustaphi, C.J., and Pisaric, M.F.: A classification for macroscopic charcoal morphologies found in Holocene lacustrine sediments. Progress in Physical Geography, 38, 734-754, https://doi.org/10.1177/0309133314548886, 2014.

Dieleman, C.M., Rogers, B.M., Potter, S., Veraverbeke, S., Johnstone, J.F., Laflamme, J., Solvik, K., Walker, X.J., Mack, M.C., and Turetsky, M.R.: Wildfire combustion and carbon stocks in the southern Canadian boreal forest: implications for a warming world. Global Change Biol. 26, 6062-6079, https://doi.org/10.1111/gcb.15158, 2020.

Enache, M.D., and Cumming, B.F.: Tracking recorded fires using charcoal morphology from the sedimentary sequence of Prosser Lake, British Columbia (Canada). Quat. Res., 65, 282-292, https://doi.org/10.1016/j.yqres.2005.09.003, 2006 Evseeva, N.S.: Geography of the Tomsk Region (Natural conditions and resources). Tomsk. West Siberian Plain Great Soviet Encyclopedia: in A. M. Prokhorov (Eds): - 3rd ed. - M.: Soviet Encyclopedia. 223, 2001.

Feurdean, A., Veski, S., Florescu, G., Vannière, B., Pfeiffer, M., O'Hara, R.B., Stivrins, N., Amon, L., Heinsalu, A., Vassiljev, J., and Hickler, T.: Broadleaf deciduous forest counterbalanced the direct effect of climate on Holocene fire regime in hemiboreal/boreal region (NE Europe). Quaternary Science Reviews, 169, 378-390, https://doi.org/10.1016/j.quascirev.2017.05.024, 2017.

Feurdean, A., Gałka, M., Tantau, Florescu, G., I., Hutchinson, S.M., Diaconu, A., Kirpotin, S.: 2000 years of variability in hydroclimate and carbon accumulation in western Siberia and the relationship with large scale atmospheric circulation: A multiproxy peat record. Quaternary Science Review, 226, 105948, https://doi.org/10.1016/j.quascirev.2019.105948, 2019.

Feurdean, A., Florescu, G., Tanţău, I., Vannière, B., Diaconu, A.C., Pfeiffer, M., Warren, D., Hutchinson, S.M., Gorina, N., Gałka, M., and Kirpotin, S.: 2020a. Recent fire regime in the southern boreal forests of western Siberia is unprecedented in the last five millennia. Quaternary Science Reviews, 244, 106495, https://doi.org/10.1016/j.quascirev.2020.106495, 2020.

Feurdean, A., Vannière, B., Finsinger, W., Warren, D., Connor, S. C., Forrest, M., Liakka, J., Panait, A., Werner, C., Andrič, M., Bobek, P., Carter, V. A., Davis, B., Diaconu, A.-C., Dietze, E., Feeser, I., Florescu, G., Gałka, M., Giesecke, T., Jahns, S., Jamrichová, E., Kajukało, K., Kaplan, J., Karpińska-Kołaczek, M., Kołaczek, P., Kuneš, P., Kupriyanov, D., Lamentowicz, M., Lemmen, C., Magyari, E. K., Marcisz, K., Marinova, E., Niamir, A., Novenko, E., Obremska, M., Pędziszewska, A., Pfeiffer, M., Poska, A., Rösch, M., Słowiński, M., Stančikaitė, M., Szal, M., ŚwiętaMusznicka, J., Tanţău, I., Theuerkauf, M., Tonkov, S., Valkó, O., Vassiljev, J., Veski, S., Vincze, I., Wacnik, A., 
https://doi.org/10.5194/cp-2021-125

Preprint. Discussion started: 4 October 2021

(c) Author(s) 2021. CC BY 4.0 License.

\section{(c) (i)}

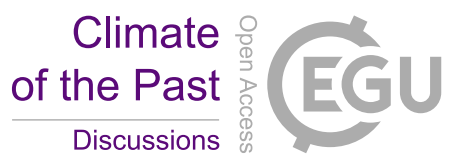

Wiethold, J., and Hickler, T., 2020. Fire risk modulation by long-term dynamics in land cover and dominant forest type in Eastern and Central Europe. Biogeosciences, 17, 1-18. https://doi.org/10.5194/bg-17-1-2020b.

Feurdean, A.: Experimental production of charcoal morphologies to discriminate fuel source and fire type: an example from Siberian taiga, Biogeosciences, 18, 3805-3821, https://doi.org/10.5194/bg-18-3805-2021, 2021.

Grospietsch, T., 1958. Wechseltierchen (Rhizopoden). Kosmos Verlag, Stuttgart.

Grooth, W.J., Cantin, A.S., Flannigan, M.D., Soja, A.J., Gowman, L.M., and Newbery, A.: A comparison of Canadian and Russian boreal forest fie regimes. Forest Ecology Management, 294, 23-34, https://doi.org/10.1016/j.foreco.2012.07.033, 2013.

Groisman, P.Y., Blyakharchuk, T.A., Chernokulsky, A.V., Arzhanov, M.M., Marchesini, L.B., Bogdanova, E.G., Borzenkova, II, Bulygina, O.N., Karpenko, A.A., Karpenko, L.V., and Knight, R.W.: Climate changes in Siberia, in: Regional environmental changes in Siberia and their global consequences Springer, Dordrecht, 2012.

Glückler, R., Herzschuh, U., Kruse, S., Andreev, A., Vyse, S. A., Winkler, B., Biskaborn, B. K., Pestrykova, L., and Dietze, E.: Wildfire history of the boreal forest of south-western Yakutia (Siberia) over the last two millennia documented by a lake-sediment charcoal record, Biogeosciences, 18, 4185-4209, https://doi.org/10.5194/bg-18-4185-2021, 2021.

Goldammer J.G., and Furyaev V.V.: Fire in Ecosystems of Boreal Eurasia: Ecological Impacts and Links to the Global System. In: Goldammer J.G., Furyaev V.V. (Eds.): Fire in Ecosystems of Boreal Eurasia. Forestry Sciences, vol 48. Springer, Dordrecht. https://doi.org/10.1007/978-94-015-8737-2_1, 1996.

Hendon, D., and Charman, D.J.: The preparation of testate amoebae (Protozoa: rhizopoda) samples from peat. Holocene 7, 199-205. https://doi.org/10.1177/ 095968369700700207, 1997.

Higuera, P.E., Sprugel, D.G., and Brubaker, L.B.: Reconstructing fire regimes with charcoal from small-hollow sediments: a calibration with tree-ring records of fire. The Holocene 15, 238-51, 10.1191/0959683605hl789rp, 2005.

Higuera, P., Brubaker, L., Anderson, P., Hu, F., and Brown, T.: Vegetation mediated the impacts of postglacial climate change on fire regimes in the south-central Brooks Range, Alaska. Ecological Monographs 79, 201-219, https://doi.org/10.1890/07-2019.12009, 2009.

Higuera, P.E., Briles, C.E., and Whitlock, C.: Fire-regime complacency and sensitivity to centennial-through millennial-scale climate change in Rocky Mountain subalpine forests, Colorado, USA. Journal of Ecology, 102, 1429-1441, https://doi.org/10.1111/1365-2745.12296, 2014.

Hudspith, V. A., Hadden, R. M., Bartlett, A. I., and Belcher, C. M.: Does fuel type influence the amount of charcoal produced in wildfires? Implications for the fossil record, Palaeontology, 61, 159-171, https://doi.org/10.1111/pala.12341, 2018.

Ivanova, G.A.: Vegetation zone-specific characteristics of scots pine forest fires in central Siberia Dr Biol. Krasnoyarsk: VN Sukachev Institute of Forest Publishing, 2005.

Ivanova, G.A., Kukavskaya, E.A., Ivanov, V.A., Conrad, S.G., MvRae, D.: Fuel characteristics, loads and consumption in Scots pine forests of central Siberia. J. For. Res. 31, 2507-2524, https://doi.org/10.1007/s11676-019-01038-0, 2020. 
https://doi.org/10.5194/cp-2021-125

Preprint. Discussion started: 4 October 2021

(c) Author(s) 2021. CC BY 4.0 License.

\section{(c) (1)}

Jensen, K., Lynch, E., Calcote, R., and Hotchkiss, S.C.: Interpretation of charcoal morphotypes in sediments from Ferry Lake, Wisconsin, USA: do different plant fuel sources produce distinctive charcoal morphotypes? Holocene 17, 907-915, https://doi.org/10.1177/0959683607082405, 2007.

Kaufman, D., McKay, N., Routson, C. et al. Holocene global mean surface temperature, a multi-method reconstruction approach. Sci Data 7, 201, https://doi.org/10.1038/s41597-020-0530-7, 2020.

Kasischke, E.S.: Boreal ecosystems in the global carbon cycle. In: Kasischke ES, Stocks BJ (eds) Fire, climate change, and carbon cycling in the boreal forest. Springer, 2010.

Kettridge, N., Turetsky, M., Sherwood, J.H., Thompson, D.K., Miller, C.A., Benscoter, B.W., Flannigan, M.D., Wotton, B.M., and Waddington, J.M.: Moderate drop in water table increases peatland vulnerability to post-fire regime shift. Scientific Reports, 5, 8063. https://doi.org/10.1038/srep08063, 2015.

Kharuk, V.I., Ponomarev, E.I., Ivanova, G.A., Dvinskaya, M.L., Coogan, S.C., and Flannigan, M.D.: Wildfires in the Siberian taiga. Wildfires in the Siberian taiga. Ambio 1-22, https://doi.org/10.1007/s13280-020-01490-x, 2021.

Kelly, R.F., Higuera, P.E., Barrett, C.M., and Hu, F.S.: A signal-to-noise index to quantify the potential for peak detection in sediment-charcoal records. Quaternary Research 75, 11-17, 2011.

Kelly, R., Chipman, M.L., Higuera, P.E., Stefanova, I., Brubaker, L.B., and Hu, F.S.: Recent burning of boreal forests exceeds fire regime limits of the past 10,000 years. Proceedings of the National Academy of Sciences, 110, 13055-13060, https://doi.org/10.1073/pnas.1305069110, 2013.

Kirpotin, S.N., Antoshkina, O.A., Berezin, A.E., Elshehawi, S., Feurdean, A., Lapshina, E.D., Pokrovsky, O.S., Peregon, A.M., Semenova, N.M., Tanneberger, F., Volkov, I.V.: Great Vasyugan Mire: How the world's largest peatland helps addressing the world's largest problems. Ambio, 7:1-2. https://doi.org/10.1007/s13280-021-01520-2, 2021.

565 Korovin, G.N.: Analysis of distribution of forest fires in Russiain. Goldammer J.G., and V.V. Furyaev, V.V.(Eds.): Fire in Ecosystems of Boreal Eurasia. Kluwer Academic Publishers, Dordrecht, The Netherlands, 2016.

Kuosmanen, N., Fang, K., Bradshaw, R.H., Clear, J.L., and Seppä, H.: Role of forest fires in Holocene stand-scale dynamics in the unmanaged taiga forest of northwestern Russia. The Holocene 24, 1503-1514, https://doi.org/10.1177/0959683614544065, 2014.

570 Kukavskaya, E.A., Ivanova, G.A., Conard, S.G., McRae, D.J., and Ivanov, V.A.: Biomass dynamics of central Siberian Scots pine forests following surface fires of varying severity. Int $\mathrm{J}$ Wildland Fire 23, 872-886, https://doi.org/10.1071/WF13043, 2014.

Kukavskaya, E.A., Buryak, L.V., Shvetsov, E.G., Conard, S.G., and Kalenskaya, O.P.: The impact of increasing fire frequency on forest transformations in southern Siberia. Forest ecology and management, 15, 382:22535, 10.1016/j.foreco.2016.10.015, 2016.

Mazei, Y., Tsyganov, A.: Freshwater Testate Amoebae. KMK, Moscow, 2006.

Magnan, G.M., Lavoie, M., and Payette, S.: Impact of fire on long-term vegetation dynamics of ombrotrophic peatlands in northwestern Quebec, Canada. Quaternary Research, 77, 110-121, 11, doi:10.1016/j.yqres.2011.10.006, 2012. 
https://doi.org/10.5194/cp-2021-125

Preprint. Discussion started: 4 October 2021

(c) Author(s) 2021. CC BY 4.0 License.

(c) (i)

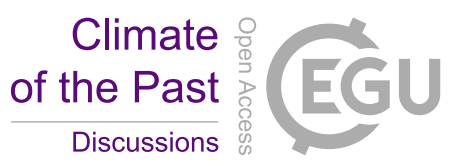

Mekonnen, Z.A., Riley W.J., Randerson, J.T., Grant R.F, and. Rogers, B.M.: 2019. Expansion of high-latitude deciduous forests driven by interactions between climate warming and fire. Nature Plants. 5, 952-958. https://doi.org/10.1038/s41477-019-04958, 2019

Moore, P.D., and Web, J.A., Collinson, M.E.: Pollen analysis. Blackwell Science, 1991.

Moritz, M.A., Batllori, E., Bradstock, R.A., Gill, A.M., Handmer, J., Hessburg, P.F., Leonard, J., McCaffrey, S., Odion, D.C., Schoennagel, T., and Syphard, A.D.: Learning to coexist with wildfire. Nature, 515, 58-66, https://doi.org/10.1038/nature13946, 2014.

Marlon, J. R., Kelly, R., Daniau, A.-L., Vannière, B., Power, M. J., Bartlein, P., Higuera, P., Blarquez, O., Brewer, S., Brücher, T., Feurdean, A., Romera, G. G., Iglesias, V., Maezumi, S. Y., Magi, B., Courtney Mustaphi, C. J., and Zhihai, T.: Reconstructions of biomass burning from sediment-charcoal records to improve data-model comparisons, Biogeosciences, 13, 3225-3244, https://doi.org/10.5194/bg-13-3225-2016, 2016.

590 Naumov, I. V.: The history of Siberia. London, New York: Routledge, 2006.

Page, S., Hoscilo, A., Langner, A., Tansey, K., Siegert, F., Limin S., Rieley, J.: Tropical peatland fires in Southeast Asia. In: Tropical Fire Ecology. Springer Praxis Books. Springer, Berlin, Heidelberg. https://doi.org/10.1007/978-3-54077381-8_9, 2009.

Ogden, C.G., and Hedley, R.H.: An Atlas of Freshwater Testate Amoebae. Oxford University Press, London.

595 Pausas J.G., and Paula, S.: Fuel shapes the fire-climate relationship: evidence from Mediterranean ecosystems Global Ecology and Biogeography, 21, 1074-82, https://doi.org/10.1111/j.1466-8238.2012.00769.x., 2012.

Remy, C.C., Fouquemberg, C., Asselin, H., Andrieux, B., Magnan, G., Brossier, B., Grondin, P., Bergeron, Y., Talon, B., Girardin, M.P., Blarquez, O.: Guidelines for the use and interpretation of palaeofire reconstructions based on various archives and proxies. Quat. Sci. Rev. 193, 312-322. https://doi.org/10.1016/j.quascirev.2018.06.010, 2018.

600 Reimer, P., Austin, W., Bard, E., Bayliss, A., Blackwell, P., Bronk Ramsey, C., . . Talamo, S.: The IntCal20 Northern Hemisphere Radiocarbon Age Calibration Curve (0-55 cal kBP). Radiocarbon, 62(4), 725-757. doi:10.1017/RDC.2020.41, 2020.

Rogers, B.M., Soja, A.J., Goulden, M.L., and Randerson, J.T.: Influence of tree species on continental differences in boreal fires and climate feedbacks. Nature Geosciences, 8, 228-234. https://doi.org/10.1038/ngeo2352, 2015.

605 Rowe, J.S.: Concepts of fire effects on plant individuals and species. In: Wein RW, McLean DA (eds) The role of fire in northern circumpolar ecosystems, 18th edn. Wiley, Chichester, 1983.

Rybina, T.A., Bazanov, V.A., and Berezin. A.E.: Spatial organization and structure of the ridge-hollow swamp complex in taiga zone of Western Siberia. Procedia Earth and Planetary Science.- (Elsevier B.V) 410 - 413, 2014.

Rudaya, N., Krivonogov, S., Słowiński, M., Cao, S., and Zhilich, S: 2020. Postglacial history of the Steppe Altai: Climate, fire and plant diversity. Quaternary Science Reviews, 249, p.106616. https://doi.org/10.1016/j.quascirev.2020.106616, 2020. 
https://doi.org/10.5194/cp-2021-125

Preprint. Discussion started: 4 October 2021

(c) Author(s) 2021. CC BY 4.0 License.

(c) (i)

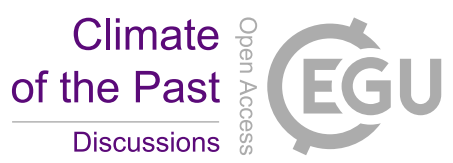

Sannikov, S.N., and Goldammer, J.G.: Fire ecology of pine forests of northern Eurasia. In: Goldammer JG, Furyaev VV (eds)

Fire in ecosystems of boreal Eurasia, Forestry Sciences vol 48.Kluver, Dordrecht, pp 151-167. . https://doi.org/10.1007/978-94-015-8737-2_1, 1996.

615 Stivrins, N., Aakala, T., Ilvonen, L., Pasanen, L., Kuuluvainen, T., Vasander, H., ... Seppä, H., 2019. Integrating fire-scar, charcoal and fungal spore data to study fire events in the boreal forest of northern Europe. The Holocene, 29, 14801490. https://doi.org/10.1177/0959683619854524.

Scheffer, M., Hirota, M., Holmgren, M., Van, Nes E.H., and Chapin, III F.S.: Thresholds for Boreal Biome Transitions. PNAS, 109, 21384-21389, https://doi.org/10.1073/pnas.1219844110, 2012

620 Tautenhahn, S., Lichstein, J.W., Jung, M., Kattge, J., Bohlman, S.A., Heilmeier, H., Prokushkin, A., Kahl, A. and Wirth, C., 2016. Dispersal limitation drives successional pathways in Central Siberian forests under current and intensified fire regimes. Global Change Biology, 22 2178-2197, https://doi.org/10.1111/gcb.13181, 2016.

Vachula, R.S., Sae-Lim, J., and Li, R.: A critical appraisal of charcoal morphometry as a paleofire fuel type proxy. Quaternary Science Reviews, 262, 106979. https://doi.org/10.1016/j.quascirev.2021.106979, 2021.

625 Walker, X.J., Baltzer, J.L., Cumming, S.G., Day, N.J., Ebert, C., Goetz, S., Johnstone, J.F., Potter, S., Rogers, B.M., Schuur, E.A. G., Turetsky, M.R., and Mack, M. C.: Increasing wildfires threaten historic carbon sink of boreal forest soils. Nature, 572, 520-523, https://doi.org/10.1038/s41586-019-1474-y, 2019.

Wirth, C.: Fire regime and tree diversity in boreal forests: implications for the carbon cycle. In: Forest Diversity and Function. pp 309-344. Springer, Berlin, Heidelberg, 2005.

630 Whitlock, C., and Larsen, C.: Charcoal as a fire proxy. In Smol, JP, Birks, HJB and Last, WM. (Eds.): Tracking environmental change using lake sediments. Volume 3: terrestrial, algal, and siliceous indicators. Kluwer Academic Publishers, 75-97, 10.1007/0-306-47668-1, https://doi.org/10.1007/0-306-47668-1_5, 2002.

Whitlock, C., Colombaroli, D., Conedera, M., Tinner, W.: Land-use history as a guide for forest conservation and management. Conservation Biology, 32, 84-97, https://doi.org/10.1111/cobi.12960, 2018.

Whitman, E., Parisien, M.A., Thompson, D.K., Flannigan, M.D.: Short-interval wildfire and drought overwhelm boreal forest resilience. Scientific Reports, 9, https://doi.org/10.1038/s41598-019-55036-7, 2019.

Whitman, E., Parisien, M.A., Thompson, D.K., Flannigan, M.D.: Topoedaphic and forest controls on post-fire vegetation assemblies are modified by fire history and burn severity in the northwestern Canadian boreal forest. Forests, 9:151. https://doi.org/10.3390/f9030151, 2018.

\section{Figures}


Figure 1. Location of the study area in Eurasia, Russia and the Tomsk region (A). Satellite based images showing the location and spatial extent of vegetation types and the fire event at the previously published sites (B; Feurdean et al., 2020a) and the new study sites: Rybnaya (C) and Ulukh-Chayakh (D).
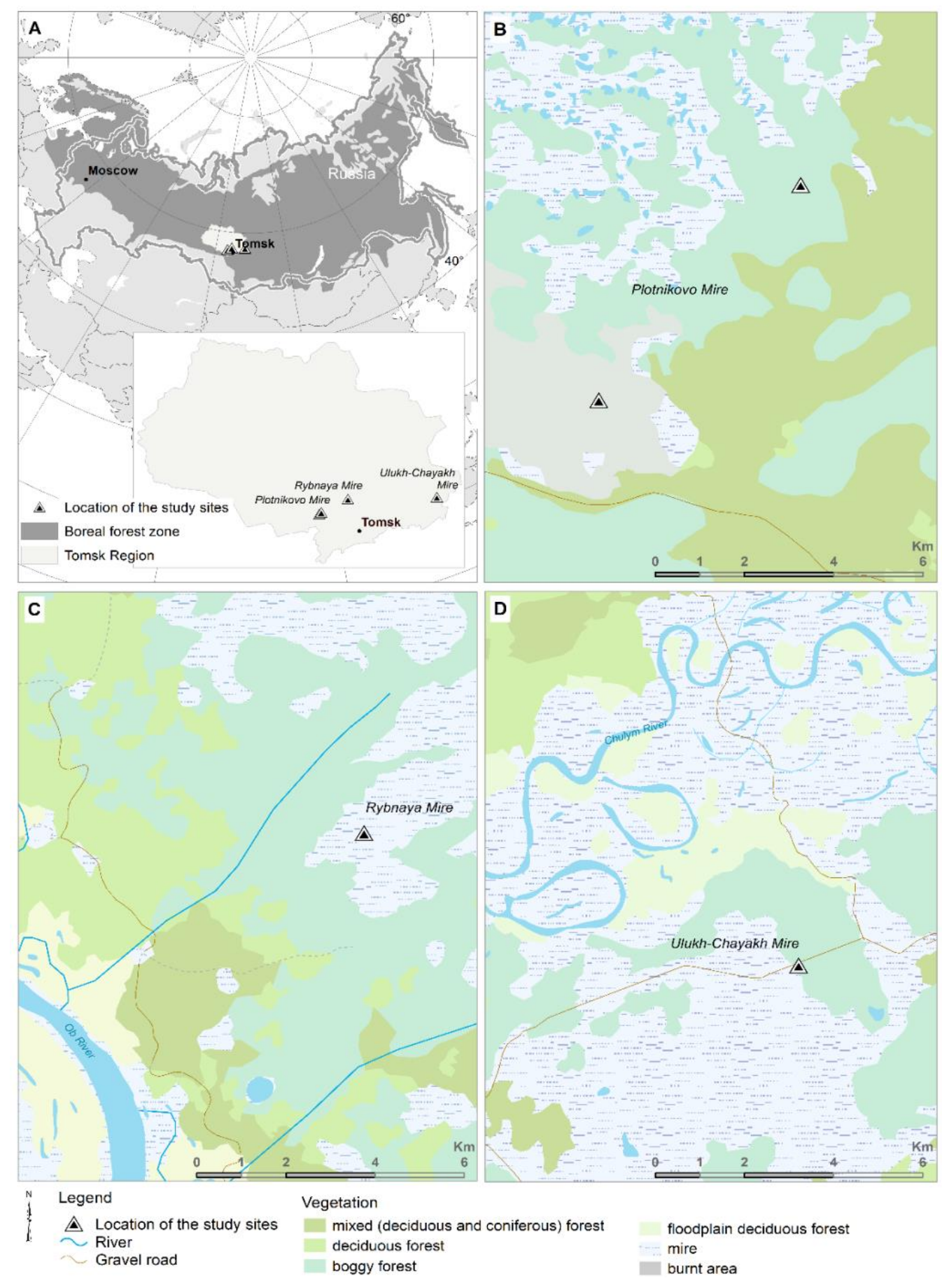
https://doi.org/10.5194/cp-2021-125

Preprint. Discussion started: 4 October 2021

(c) Author(s) 2021. CC BY 4.0 License.

(c) (1)

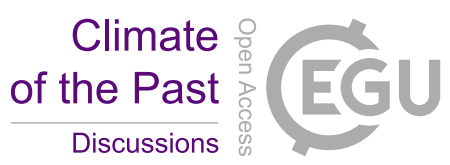

650

Figure 2. The ratio of charcoal morphotype influx $\left(\# / \mathrm{cm}^{-2} \mathrm{yr}^{-1}\right)$ of the two main categories: woody (wood, deciduous leaves, resins) and non-woody type (forbs, grass) in the Rybnaya (a) and Ulukh-Chayakh (b) sequences. The aspect ratio $(L: W)$ at Ulukh-Chayakh (b) used for fuel type identification. A high $L: W$ ratio is typical for a higher abundance of the graminoids charcoal type, whereas a lower $L: W$ ratio is typical for charcoal from wood and leaves. The ratio of charcoal influx $\left(\# / \mathrm{cm}^{-2} \mathrm{yr}^{-}\right.$ ${ }^{1}$ ) of the two main two size classes: small 150-500 $\mu \mathrm{m}$ and large $>500 \mu \mathrm{m}$ in the Rybnaya (c) and Ulukh-Chayakh (d) sequences and the charcoal surface area $\left(\mu \mathrm{m}^{2}\right)$ at Ulukh-Chayakh (d) (see File S3 for a full range of size classes). Bullets (b) represent the extra-large charcoal fraction (>1000 $\mu \mathrm{m}$ ) identified during routine plant macrofossils analysis of sediment volumes of ca. $20 \mathrm{~cm}^{3}$. The grey rectangle highlights the period with uncertain chronology.

660
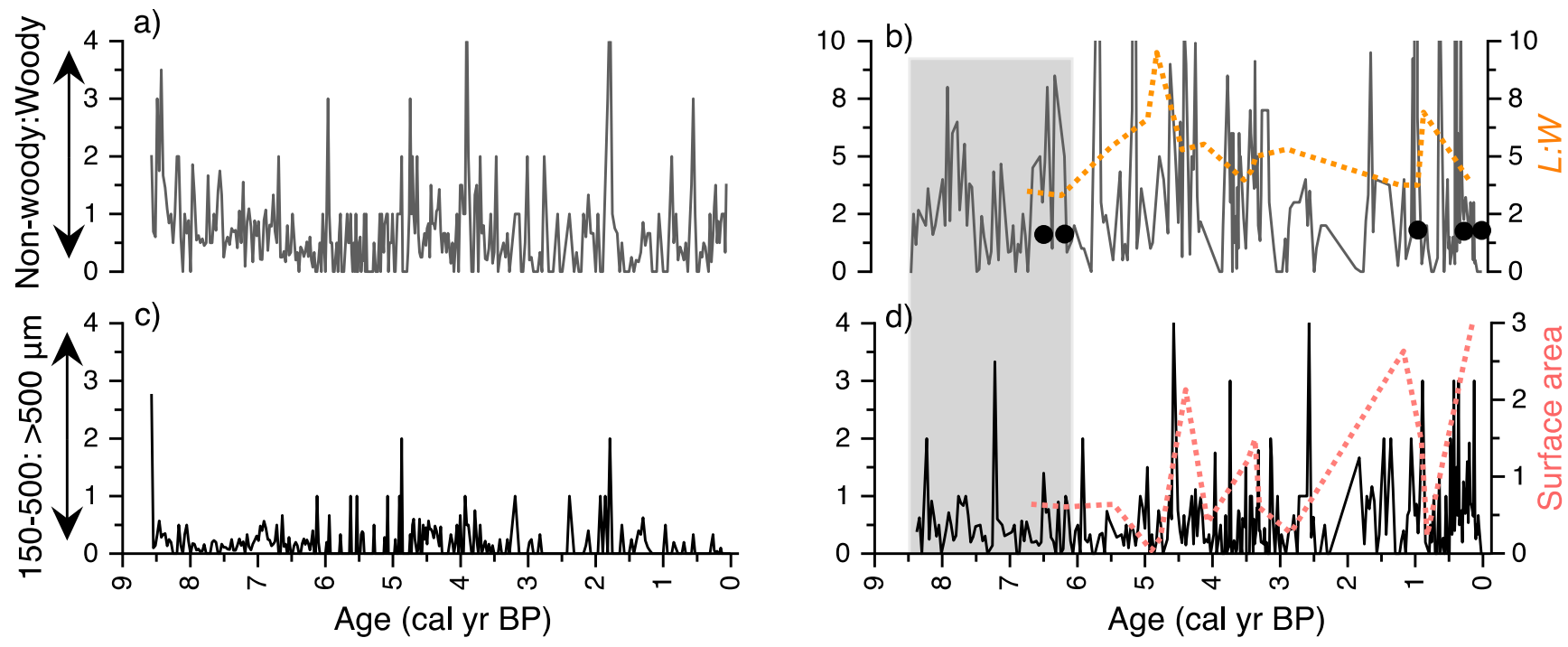

665 
https://doi.org/10.5194/cp-2021-125

Preprint. Discussion started: 4 October 2021

(c) Author(s) 2021. CC BY 4.0 License.

(c) (1)

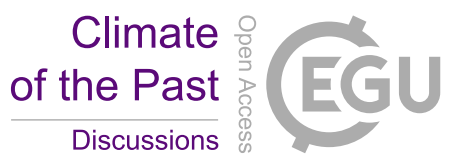

Figure 3. Temporal trends in the pollen and spore percentages of individual tree taxa and lumped group-wise for shrub, herb, fern and moss at Rybnaya (continuous line) and Ulukh-Chayakh (dashed line). Periods with substantial changes in fire regime 675 are indicated by dotted vertical lines.

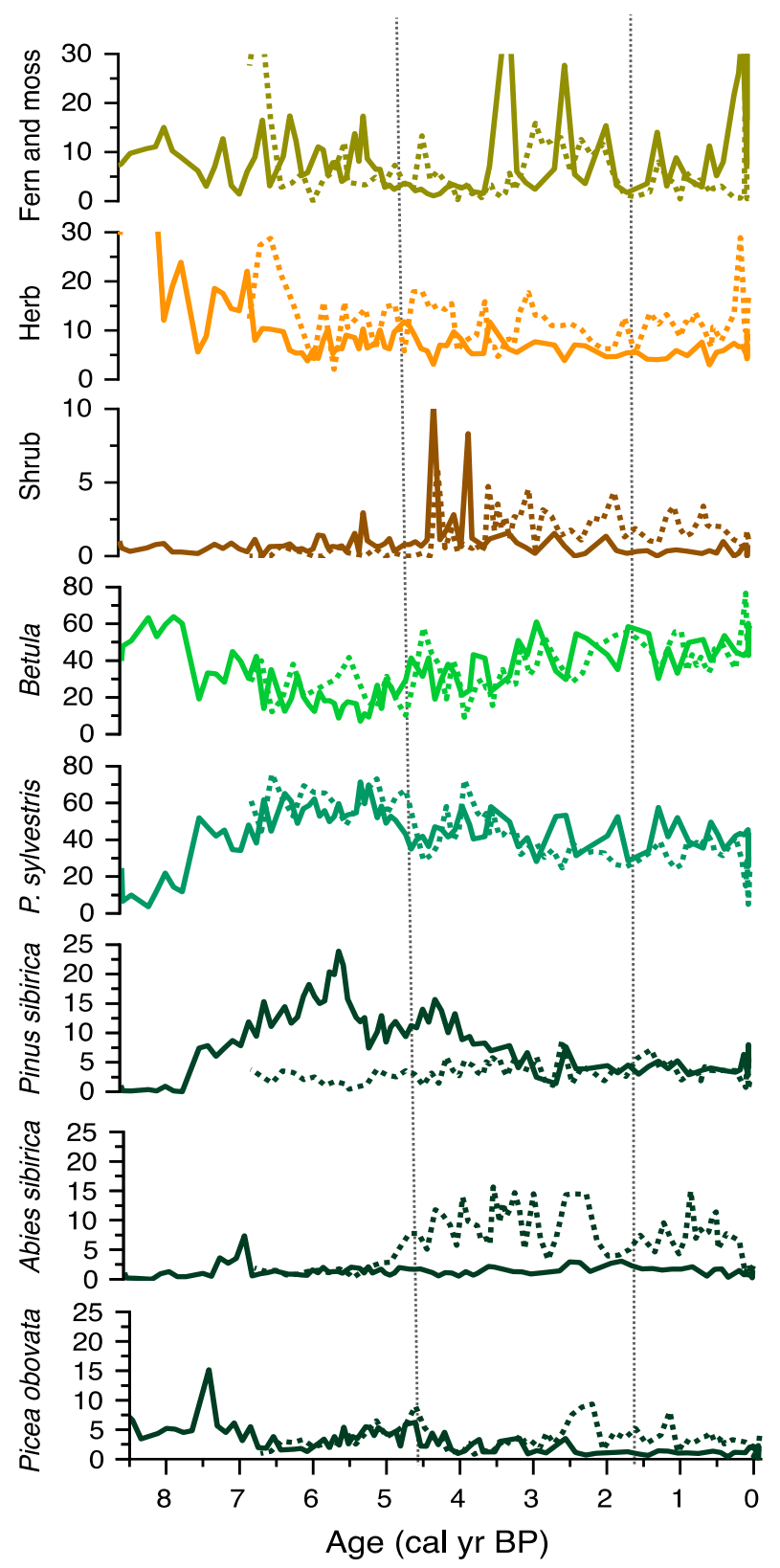


https://doi.org/10.5194/cp-2021-125

Preprint. Discussion started: 4 October 2021

(c) Author(s) 2021. CC BY 4.0 License.

(c) (1)

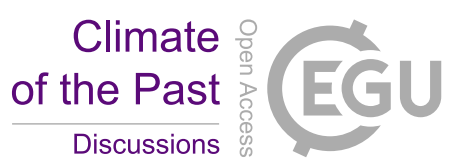

Figure 4. Temporal trends in the pollen percentages of the fire-related plant functional groups (invaders, resisters and avoiders) and the forest density index determined from the ratio between pollen percentages of dark taiga/ and light taiga tree taxa in the

680 Rybnaya and Ulukh-Chayakh sequences. Hydrological conditions on the peatlands were derived from testate amoeba-based estimates of the water table location (DTW) where values range from $8 \mathrm{~cm}$ (high water level) to $30 \mathrm{~cm}$ (low water level). The fire metrics include burned biomass (CHAR), fire frequency (number of fires /900 years), and charcoal peak magnitude (the higher the values, the greater the fire severity) derived from macro-charcoal particles $>150 \mu \mathrm{m}$. Colours in the background denote periods with marked changes in fire regime and vegetation composition, where a change from blue hues to orange hues 685 indicates an intensification of the fire episodes. 

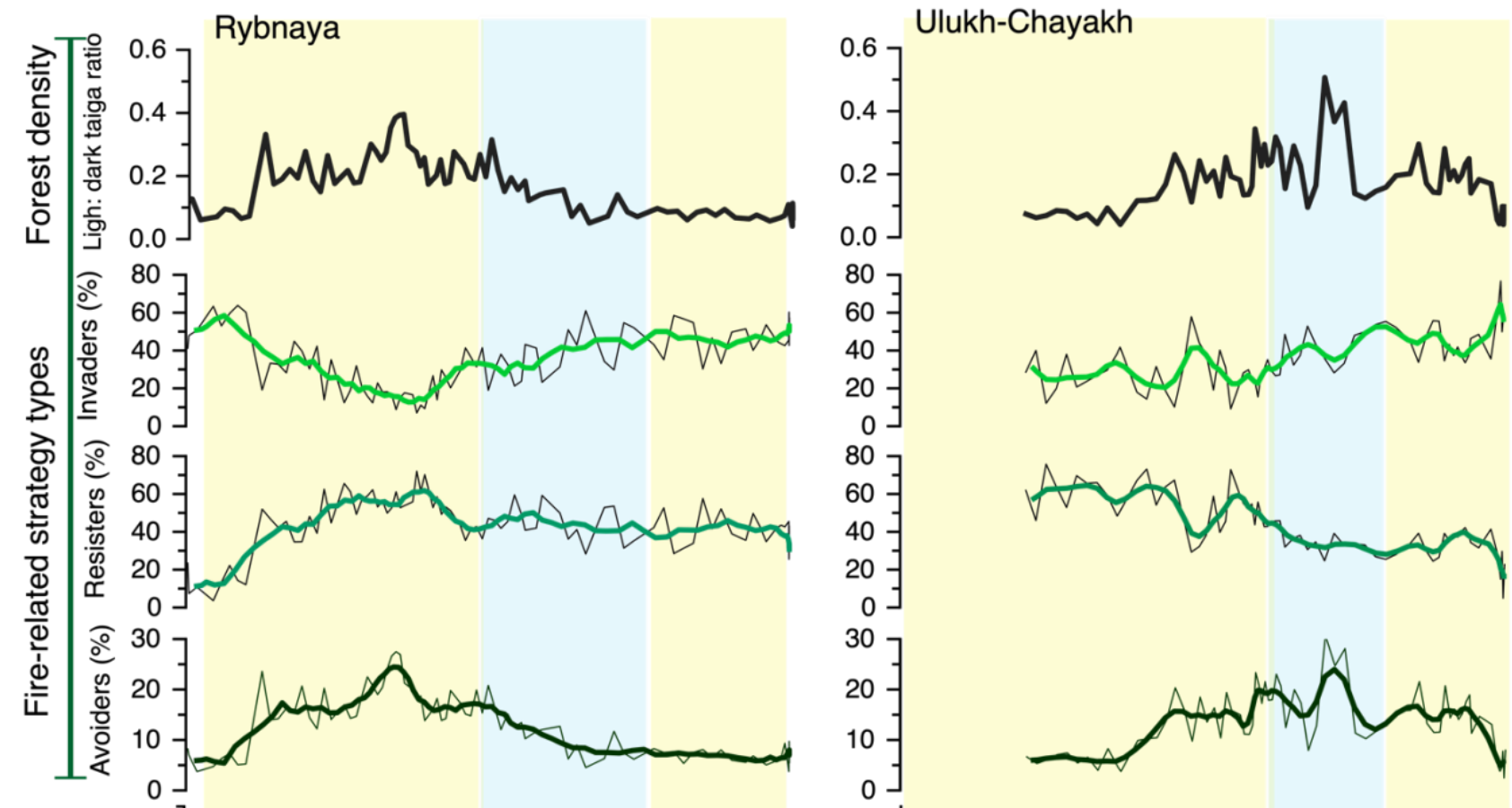

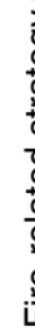

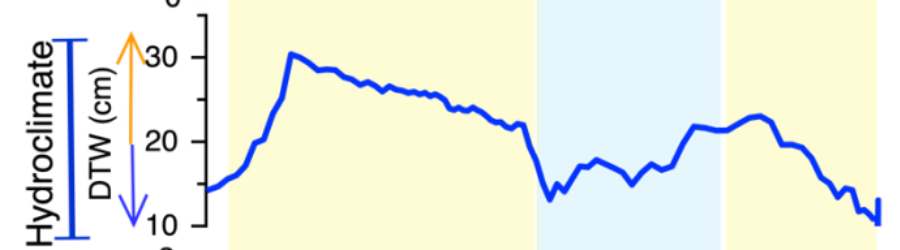

80
60
$40-1$
20
0.7
0.7

-
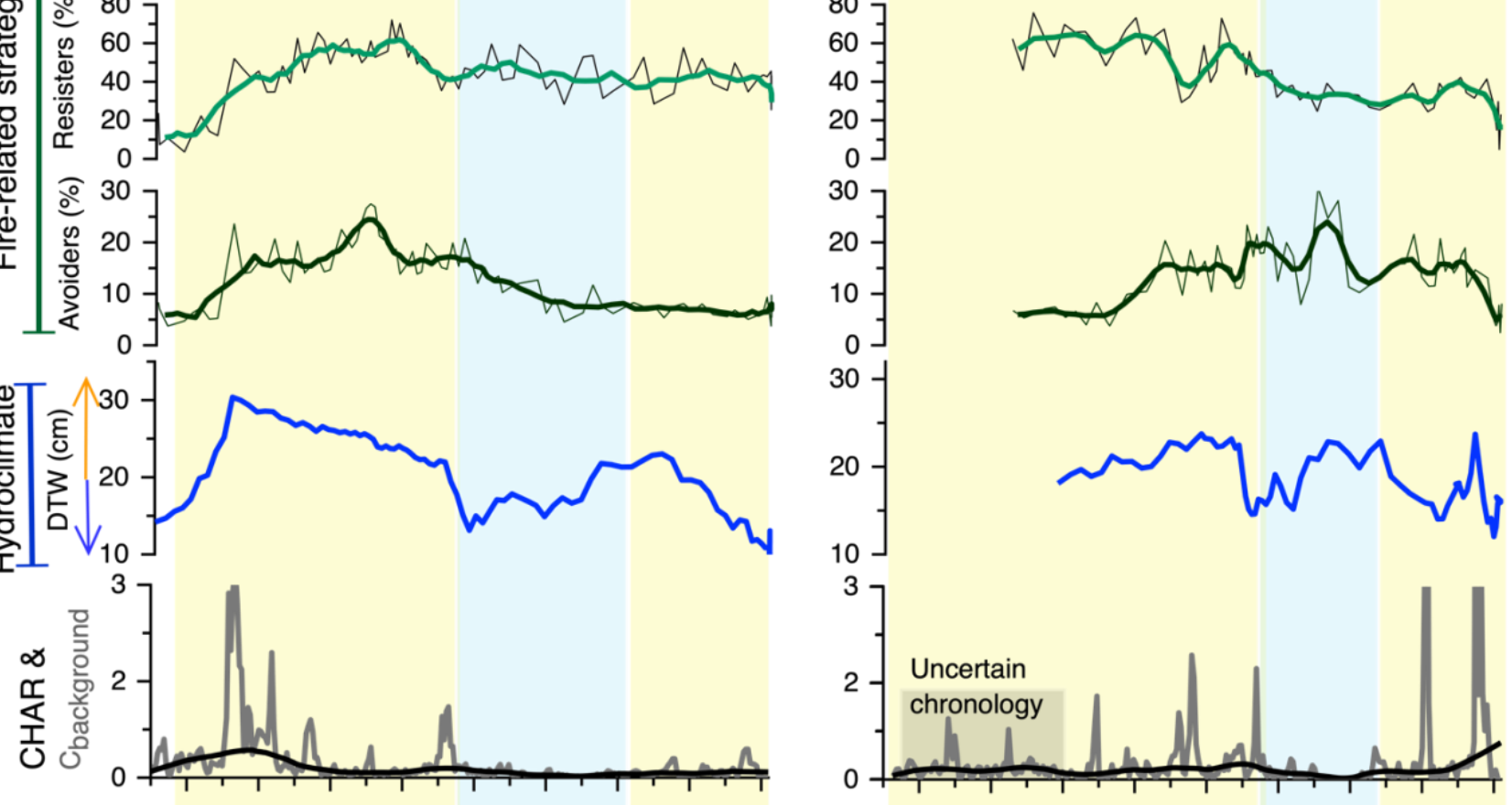

20
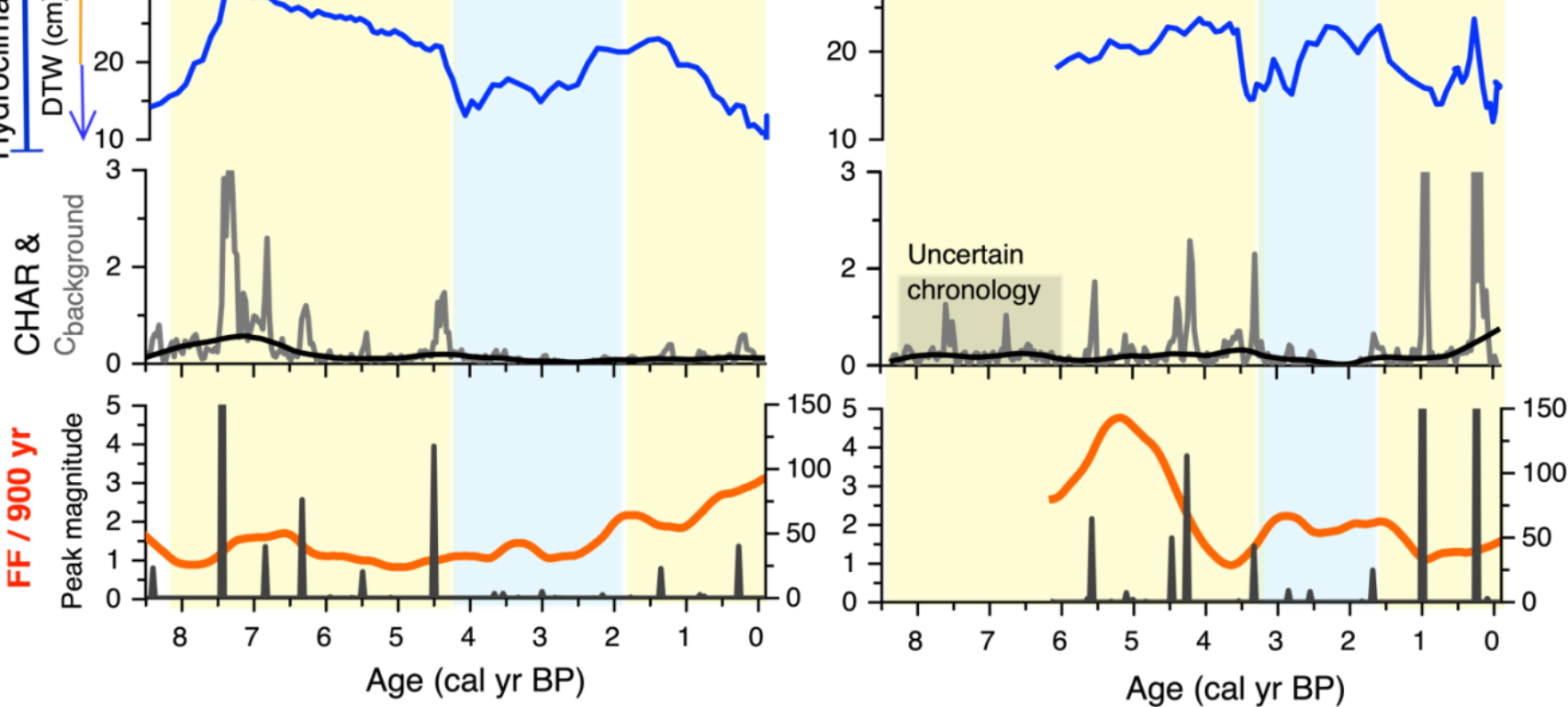
https://doi.org/10.5194/cp-2021-125

Preprint. Discussion started: 4 October 2021

(c) Author(s) 2021. CC BY 4.0 License.

(c) (i)

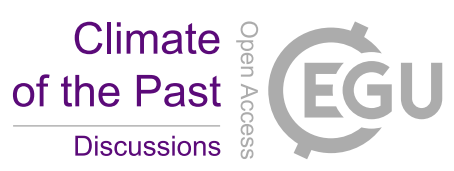

700 Figures 5. Composite record of biomass burning $(n=4)$ based on $\mathrm{Z}$-score charcoal influx where positive/negative $\mathrm{Z}$-score values represent greater-than-mean/lower-than-mean charcoal influx over the base period (a). Composite record of fire frequency $(n=4)(b)$. Composite record of peatland hydrology $(n=4)$ from testate amoeba where positive/negative Z-score values represent lower/higher-than mean water level (c). Annual temperature (anomalies) for 30-60 ${ }^{\circ} \mathrm{N}$ (Kaufman et al., 2020) (d). Composite record $(n=4)$ of the relative abundance of avoiders, resisters, and invaders determined from pollen percentages (e). Grey curves represent confidence intervals. Colours highlight the periods with higher biomass burning in the composite record.
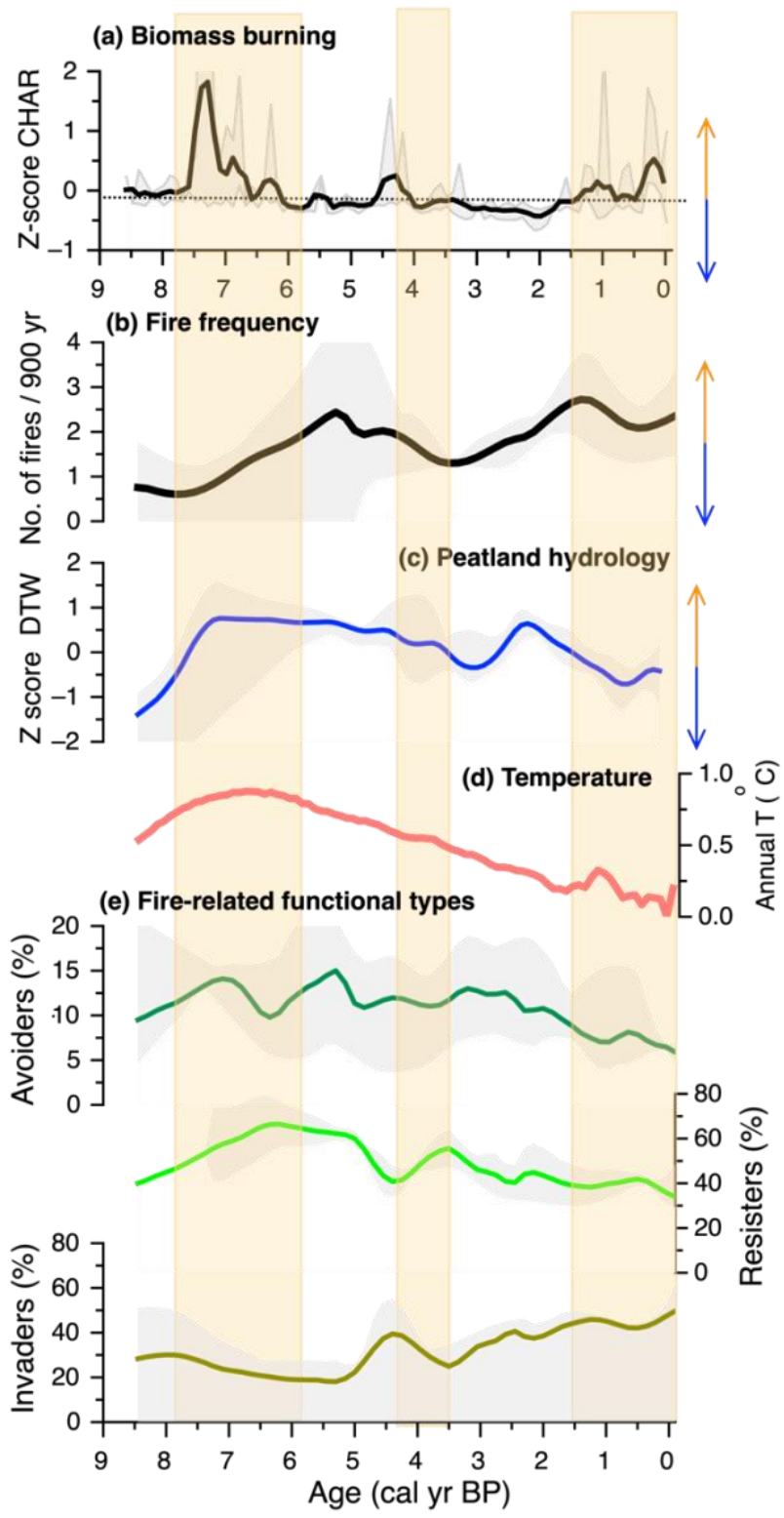
https://doi.org/10.5194/cp-2021-125

Preprint. Discussion started: 4 October 2021

(c) Author(s) 2021. CC BY 4.0 License.

(c) (i)

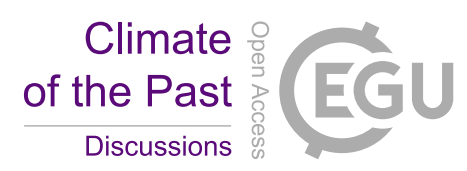

710 Figure 6. Correlation analysis between water table position and the main plant functional types and forest density for Rybnaya (a) and Ulukh-Chayakh (b). Generalised linear models (GLMs) showing the response of biomass burning (CHAR) to changes in peatland moisture conditions (higher values in depth to water table=DTW representing drier conditions) for Rybnaya (c) and Ulukh-Chayakh (d).

a)

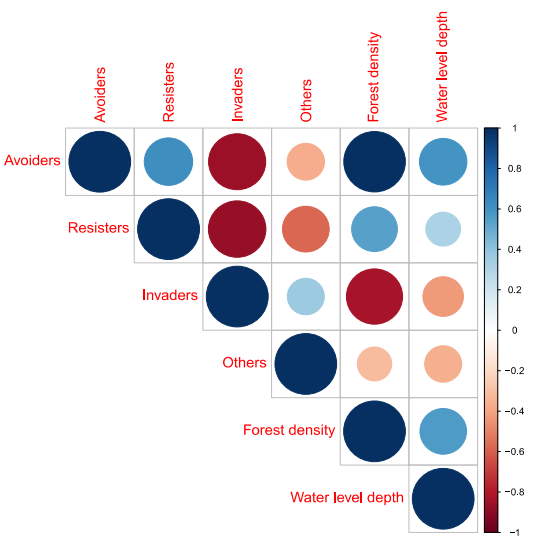

c)

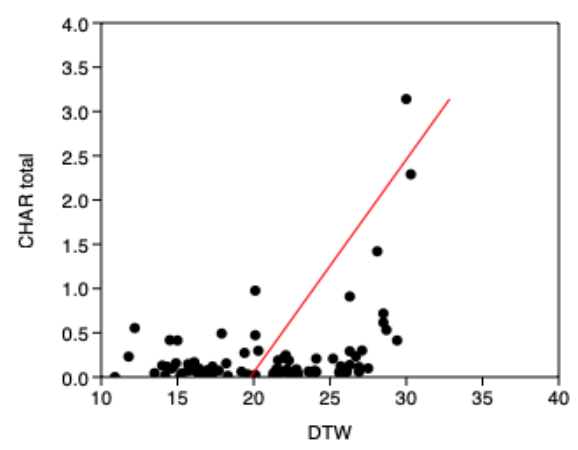

b)

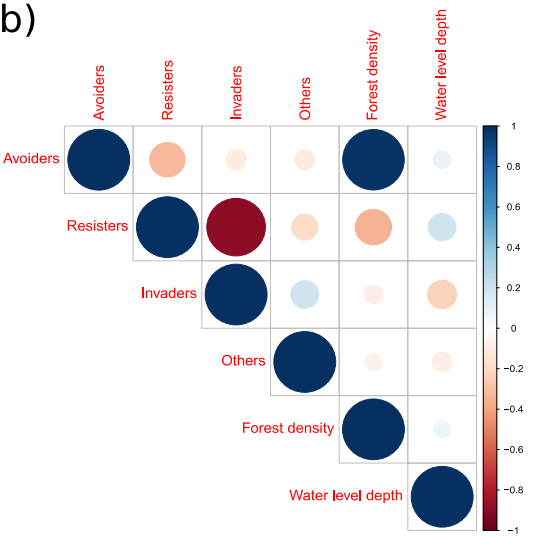

d)

$y=-0.58987 x+19.603$

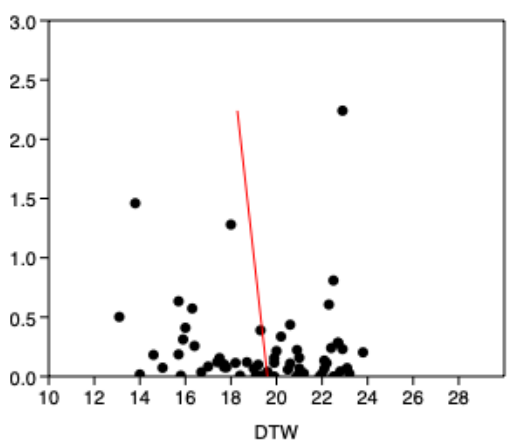

